Portland State University

PDXScholar

\title{
Myths and Measures: The Cultural Performance of Portland's Strip Club Identity
}

Wayne Coffey

Portland State University

Follow this and additional works at: https://pdxscholar.library.pdx.edu/geog_masterpapers

Part of the Geographic Information Sciences Commons, and the Human Geography Commons Let us know how access to this document benefits you.

\section{Recommended Citation}

Coffey, Wayne, "Myths and Measures: The Cultural Performance of Portland's Strip Club Identity" (2012). Geography Masters Research Papers. 14.

https://pdxscholar.library.pdx.edu/geog_masterpapers/14

10.15760/geogmaster.14

This Paper is brought to you for free and open access. It has been accepted for inclusion in Geography Masters Research Papers by an authorized administrator of PDXScholar. Please contact us if we can make this document more accessible: pdxscholar@pdx.edu. 


\begin{abstract}
Identities of place develop through a multitude of perceptions. Place myths guide much of this perception. Portland, Oregon's identity has evolved in particular around a much quoted but unchallenged statistic regarding the volume of nude dancing venues. This paper focuses on the literature specific to both nude dance venues and place identity; Portland's legal history that contributed to this phenomenon; and some of the cultural and spatial variables pertinent to this issue. Two initiatives, aimed at restructuring the state constitution specifically to deal with nude dance venues and other adult entertainment, are analyzed.
\end{abstract}


Myths and Measures: The Cultural Performance of Portland's Strip Club Identity

\author{
By \\ Wayne Coffey
}

A research paper submitted for the fulfillment of the degree requirement of

\author{
Master of Science \\ In \\ Geography
}

Portland State University

2012 


\section{Table of Contents}

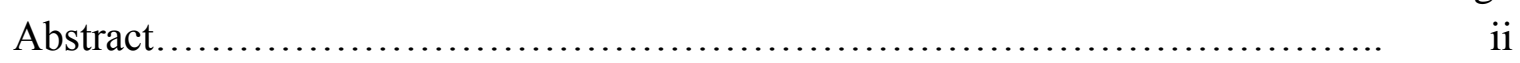

Introduction...................................................... 1

Literature Review.................................................... 9

Historic Background ................................................. 18

Origins of Burlesque and Striptease................................ 18

Oregon's Constitution and Portland Strip Clubs........................... 22

Oregon's "Anti-Porn” Ballot Measures and the Liquor Control Commission..... 25

The Liquor Control Commission and Oregon Courts Revisited................. 30

Controversy Persists................................................ $\quad 32$

General Discussion................................................... 34

Exotic Dance in the Context of the Strip Club Setting....................... 35

Relational Space as Social and Spatial Practice........................... 37

Place Identity and Portland's Strip Club Culture.......................... 41

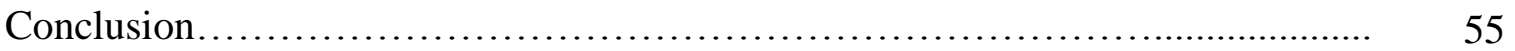

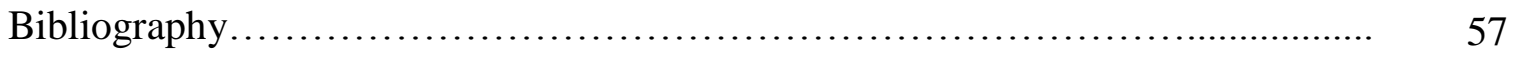

Appendices

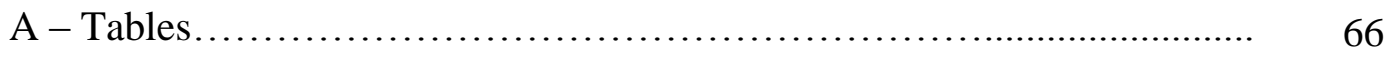

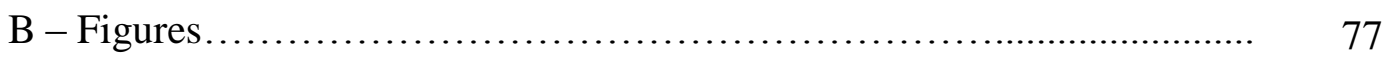

C - Methodologies Statements ................................... 84

D - Ballot Measure Statements................................... 86 


\section{Myths and Measures: The Cultural Performance of Portland's Strip Club Identity}

\section{Introduction}

Places emerge through recognition. The recognition can be real or imagined and by persons residing within or outside the identified space. Recognition also results from some distinguishable characteristic(s). The act of recognizing and establishing the identity of a place is a long tenured ritual from the primal ceremonies of walking village boundaries to the contemporary fetish with regional boosterism (Tuan, 1977). Portland, Oregon boasts many promotional statistics from library book circulation to coffee consumption. It also has the dubious, yet unofficial, distinction of having the most strip clubs (nude dancing establishments) per capita of any U.S. city.

The continued citation of this factoid in media and public discourse rarely includes discussion of the merit of the source's origin, that is, it would appear to be a baseless claim. The expression of a place's identity seems ever changing and the forces that shape that expression can be hard to define. For the Portland region, attitudes about the status as a strip club capital can be summarized into three general groups. The first appear as a vocal, though nebulous, population that embraces diversity, rebelliousness, and transgression as a defining element of local culture. The second, a distinct but fragmented voice of citizen, social welfare and business groups, reject strip clubs as a legitimate part of the cultural tapestry. The third, an ambivalent majority, appear to accept the current condition as status quo. Myths of a place derive from facts mediated through belief and power. Place identity is an arena in which contested ideas and values 
struggle over what (or whom) determines the means of representation. These ideas can coexist in a casual tolerance but at times conflicts aggravate this peace. This persistent dialogue has a defining impact on the mythologized geography of Portland.

Adult entertainment, from internet pornography to live exotic dancing, poses problems for communities. Whether real or imagined, these problems may be social some prostitution and sexual assault can be related to adult entertainment - but are largely cultural in that they involve conflicts over a community's identity. This problem can be seen in both terms of a moral code (you can't do that) and a spatial code (you can't do that here). Sexually explicit material and performances are afforded some protection by the first amendment of the U.S. constitution. In Oregon, they are afforded much greater protection. The emphasis here is on the spatial code - the question of where adult entertainment occurs - which shifts considerably depending on the legislative environment of each state or city. However, moral codes are applied spatially, by determining what is in place or out of place (Cresswell; 1996, 2005).

While the internet can not usually be targeted as a source of one community's problems in particular, conspicuous commercial venues that deal sexually explicit material are targeted in the landscape typically as blight and rarely accepted as part of the larger commercial tapestry of local businesses. Venues supporting exotic dancing as public spectacle (generally referred to as strip clubs and for the remainder of the paper will be referred to as such) are distinct from other entertainment venues. This distinction and the disproportionate amount of attention strip clubs receive compared to other adult venues is one element of how Portland performs identity. That identity extends from 
myths about how communities want to be perceived. As the presence of strip clubs becomes commonplace in the landscape they come to symbolize resistance to a larger struggle against modernity (Harvey, 1990; Massey, 1994).

Places, whether as political or cultural entities (neighborhoods, cities, regions), define themselves in part through the behaviors and values of their populace. These behaviors and values are expressed sometimes as acts of civic organization such as historic preservation (buildings, trees) or monumental artifice (stadiums, parks) but also acts of consumption like food and entertainment. While strip clubs have their own internal conflicts, local tabloid publications in Portland and websites revel in the representations of strip clubs as conventional entertainment for normal consumption that also stand out as deviant within the context of national identity. This deviance may represent a deep chauvinistic undercurrent or a preponderance of excessive "perversion" but within the locus of cultural transgression in Portland society, the mythical status as "strip club capital" signifies a greater reconciliation with the complex resistances present in any city (Harvey, 1990).

The status as "strip club capital" derives first from reports by police in the early 1990s (Zimmerman, 1993) and reinforced by internet surveys by taken across the country, undertaken mostly by alternative weekly publications and Measured against the local population counts (Moore, 2005). The result is the number strip clubs per capita, which Portland has consistently had the most of since the poll was initiated. The Measure is arbitrary. Methods for how to accurately qualify what constitutes a strip club (from a peep show or a bar with topless wait staff for example) and to distinguish the degree of 
activity (number of dancers and extremity of acts) are absent while the use of city populations creates great spatial anomalies with regards to how these clubs interact with the surrounding urban/rural environment. Local booster organizations do not tout such measures as part of their promotional campaigns but the continued reporting of the per capita statistic by most media outlets has made the issue a pervasive one in the cultural dialogue.

The idea of strip clubs as pervasive perhaps establishes another celebratory dimension to the character of the city as a laboratory for expressing resistance. It also provides a platform for more diverse political discourse, that is, what does the success of so many clubs and the defeat of obscenity measures (ballot initiatives) say about the populace? At one perspective, a pervasive strip club culture demonstrates how a state with a rigid land-use system can simultaneously juxtapose the subtlety of its unique constitutional free expression clause. However, this pervasiveness also exposes the everpresent employment disparities between men and women and a recognizable imbalance in sexual roles (male strippers are a stark minority). Or perhaps instead of demonstrating a flexible, competent and pro-active government it displays the folly of an impotent system at the mercy of a global sex industry.

The persistent growth of adult entertainment represents one part of a larger ongoing development of the changing nature of urban space. While most adult electronic media (pornography) has moved off the street onto the internet, strip clubs have expanded their territory, moving from the clustered low-rent districts of downtowns and the rural fringes into more diffuse patterns centering in suburban neighborhoods and high-profile 
commercial areas (Ryder, 2004). It is necessary to differentiate the role place has as local agent in this shifting cultural terrain (Massey, 1994). The strip club functions sociologically as a venue for men (and women) to act out hetero-normative behaviors no longer acceptable in the wider public view. Strip clubs are intentionally unfulfilling in the masochistic sense (Uebel, 2004). In the same way that exotic dancers are theorized to negotiate their identities through the exchange of power on the stage (Egan, 2006; Law, 1997), the venues themselves also play out this negotiation in the landscape. This negotiation performs as transgression in many circumstances, ever-challenging what is in-place or out-of-place (Cresswell, 1996). Transgression opens discourse between sites (and people) leading to recognition of previously absent or unseen cultural boundaries perpetuating a pattern of spatialization (Shields, 1992).

Portland's identity as strip club mecca can be seen as a product of media distortion of facts, used to the advantage both of opponents of adult entertainment as well as adult entertainment industry leaders trying to promote themselves into more acceptable recognition. As the public has participated in three ballot initiatives to decide the fate of constitutional wording that protects adult entertainment as free $\operatorname{speech}^{1}$, the interaction of political celebrities like Kevin Mannix and the ACLU presents the issue as a fight between social conservatives and libertarians. While family values and free speech are interminably fated to fierce discourse, the issue over Portland's (and Oregon's) strip club

\footnotetext{
${ }^{1}$ Free speech and free expression are synonymous and exchanged intermittently in most media and scholarly print. While the term "speech" is used in the originating constitutional language, the legal president has come to recognize speech as including many forms of expression including dance. The contested line regarding striptease, exotic dance, and nudity centers on the distinction between "activity" and "expression".
} 
identity is more complex than simply prude versus lewd. The current interpretation of the Oregon constitution's free speech clause is drastically more open than the federal courts', specifically citing protection for offensive speech and/or expression. No other state has such an interpretation, and adult entertainment has time and time again been the lightning rod issue to test the constitution's free speech clause (Hanna, 2005).

Adult entertainment does not flourish simply because the law allows it - there must be demand. For strip clubs the demand amounts to over two billion dollars yearly nationwide (Schlosser, 2003). While legal scholars and community activists argue over the acceptable location and permissible activities for adult venues, the adult business industry grows. And though state legislators and city administrators' posture against the growth of the industry, real constituents participate in Portland's strip club identity daily. Dancers, patrons, and club staff (bartenders, servers and bouncers) comprise the primary actors while club owners, vendors and other entertainers (DJs and musicians) comprise secondary actors. Behind this are the regulating agencies. Greater dependency on state agencies, such as the Oregon Departments of Health and Revenue and especially the Oregon Liquor Control Commission (OLCC) to regulate strip clubs has grown as local municipalities have less jurisdiction over adult entertainment or are too constrained financially to police these venues, and yet the OLCC's regulating abilities have also been greatly diminished more recently.

The impasse created by the court rulings on free speech in the 1980s and the inability by lawmakers to find an adequate regulating solution for adult oriented business still persists. Conflicts continue to erupt in communities previously unbothered by adult 
entertainment (typically in suburban Portland cities) but also in areas with a well established concentration of business, like Beaverton west of Portland.

Answering the question of why there are so many strip clubs is not the aim here. The intention is to present the complexity of the issue, examine the history of conflict, and discuss the factors that have contributed to the debate as it pertains to Portland's identity. To further explore the issue, I have provided detailed segments - each with a significant perspective. A brief literature review describes the most current material relevant to place identity, cultural performance and adult entertainment in the form of strip clubs. An historical and legal chronology of exotic dance and its relation to burlesque integrates the legal history of public nudity and obscenity as it relates to Oregon's Constitution and the promulgation of adult entertainment. A general discussion integrates the literature, history, anecdotal evidence and data analysis generated from research and observation. 


\section{Literature Review}

Early research of exotic dance focused on strippers as subjects for deviance studies (as noted by Frank, 2007 and Hanna 2010). Changing perspectives on research regarding exotic dance have grown to incorporate more nuanced analysis of dancers, patrons, clubs and places involved in the activity. Yet the evolution of research has fallen short of better recognizing strip clubs' visibility in the everyday public consciousness. Moreover, research on strip clubs appears to not recognize the mythologizing force the clubs, individually or as an entity, may have on place identity.

Tuan and Shield's focus on the promotion of myths for place distinction (1977; 1992). Other research has focused on the recognition of identifiable place characteristics as part of myth creation (Park and Burgess, 1925/1984; Harvey, 1989; Massey, 1994). Research also addresses the role of social practice as performance in producing place identity, recognizes transgression as symbolic of unfixed place identity, and examines the need to authenticate experiences in the landscape as real or imagined (Cresswell, 1996; Edensor, 2002; Frank, 2002; Murdoch, 2006) ${ }^{2}$.

Research related to exotic dance and strip clubs has increased over the last two decades. Historical documents of burlesque and striptease as uniquely American art forms provide general knowledge of the subject (Allen, 1991; Jarrett, 1997). Over time the emphasis has shifted from the dancer's experience as deviant or victimized, to one of fluctuation between exploited and empowered, and eventually toward the clubs

\footnotetext{
${ }^{2}$ This comprises only a brief list of research on such a general subject.
} 
themselves as spaces where power roles are negotiated and traditional identities of masculine and feminine are both reinforced and undermined (Forsyth and Deshotels, 1998; Schiff et al, 1999; Erickson and Tewksbury, 2000; Schweitzer, 2001; Barton, 2002 and 2007; Bruckert , 2002; Egan, 2003; Frank, 2003; Murphy, 2003; Uebel, 2004; Mestemcher and Roberti, 2004; Lewis, 2006; Bradley-Engen and Ulmer, 2009). Research has also focused on the relationships among dancer, patron, and club staff within the environments of strip clubs and identified the use of spatial arrangements and social organization to establish predictable and normative male spaces while also increasing the flexibility and autonomy of the dancers' work mode (Erickson and Tewksbury, 2000; Sweet and Tewksbury 2000; Lewis, 2006; Bradley-Engen and Ulmer, 2009). This normative male space contrasts with cultural spaces beyond the strip club, and the real or imagined relationships formed between dancer and patron extend to the relational networks developed outside the clubs (Barton, 2002; Bruckert, 2002; Frank, 2002 and 2003; Egan, 2003 and 2006; Uebel, 2004; Whitehead and Kurz, 2009).

Recent research considers strip clubs as specialized symbols representing contested attitudes about permissiveness in the context of a moral geography (Symansky, 1981; Smith, 2000; Foley, 2002; Ryder, 2004; Cresswell, 2005; West and Orr, 2007; Danta, 2008, Hubbard 2009, Wahab, 2010). Researchers have examined the social constructions of adult entertainment consumption, and to a lesser degree, on community perceptions about crime, zoning, and morality as they relate to interior experiences and establishment locations (Schiff et al, 1999; Hanna 2003, Frank 2002, West and Orr, 2007). The visibility and location of adult entertainment districts is subjected to 
regulatory pressure by community groups and municipal governments. The constituents of these contests are rarely aligned equally in their goals against adult entertainment districts (Foley, 2002; Ryder, 2004; Danta, 2008, Hubbard 2009) ${ }^{3}$.

Elements that contribute to experiences carried into and taken away from strip clubs have been chronicled but are still are far from comprehensive. While a number of ethnographic accounts by researchers have illuminated dancers' individual accounts (Forsythe and Deshotels, 1998) and attempts to describe variables in dancers' work motivations (Sweet and Tewksbury, 2000), very little work has attempted to capture a more aggregate picture of strip clubs and dancer/patron experiences or the social organization constructed by clubs (Bradley-Engen and Ulmer, 2009). This can be attributed to the sparse and inconsistent data gathered thus far, a result of the subject's complexity and the elusiveness of the actors.

Dancers have been willing subjects for researchers (who have almost exclusively worked in the trade) but are not usually available for follow up or longitudinal studies (Frank, 2007). Patrons have proven equally elusive and fewer in number. Regulars comprise the majority of patron research subjects and their participation has been predicated upon the implication of perceived relationship between dancer/researcher which inevitably dissolved (Egan, 2006; Frank, 2002). Thus no empirical understanding of anything beyond a particular club or dancer can be explored at this time.

\footnotetext{
${ }^{3}$ Social conservative, neighborhood association, and feminist/women advocacy groups have found themselves loosely unified in conflicts over the regulation of adult entertainment. Divisions within each group's agendas range in dimension from property values to traditional values to the societal role of women. The issue has proved divisive among academic feminists as illustrated by Butler (1993) and Kipnis (2003).
} 
The experiences that accumulate within and across multiple clubs are then theoretical assumptions that may or may not be correct. However, Bradley-Engen and Ulmer (2009) have presented the most extensive data thus far and distinguish a variety of experiences incumbent upon a club's social and spatial organization. They identified three categories of clubs, each with its own package of codes and systems to promote a profitable atmosphere, and each type progressively less desirable for dancers to work in.

Researchers Frank $(2002,2007)$ and Egan $(2003,2006)$ represent the axis of cultural research on exotic dance, strip clubs and their patrons. Both have redirected the conversation concerning dancers away from dichotomies about deviance and victimization toward one that gives agency to the dancer's position and suggests a multitude of experiential representations. Neither argue that strip clubs are not exploitive environments (no research appears to argue that), but that a strip club is emblematic of a greater societal pattern experienced by women (and men). Frank and Egan argue that exotic dance and strip clubs are not the obtuse artifacts of modern human experience, part of some hidden sub-culture, as conventional ideology insists.

Frank (2002 and 2007) has further argued that research on strip clubs needs to move beyond the dancer and patron and examine the social, spatial, and cultural relationships present in the periphery of the strip club milieu. Frank and Egan have both incorporated elements of cultural geography into their critiques. Frank (2002) considers strip clubs as dominant landscape features of her study area and part of the wider public consciousness. Frank (2002) examines the use of public and private space to delineate a moral and spatial code, and explores the social geographies of race and class among 
dancers and patrons. Egan (2003 and 2006) emphasizes the inner geographic landscape of the strip club noting the positionality of social class within the club and the ways the spatial structure constructs and reinforces identities of gender and power. Egan (2003) also considers the tenuous boundary between regular patrons' perceptions of emotional relationships and how the club demarks a zone of intimacy that is only authenticated by a challenge to carry the relationship beyond the club space.

Further research into the spatial parameters of strip clubs and/or other adult entertainment/sex work is compelled by Frank's appeal to a greater breadth of research across disciplines. Research presented here has thus far only considered the interior spaces of club environments and given a superficial treatment to the broader spatial/geographic perspectives on strip clubs. More synthesis is needed. The concepts of myth, visibility, performance, and transgression that have been researched in the context of geographic literature need to be reconciled with subject constituents and the relational space that emerges from the themes of hyper-gendered identities and conflated moral codes.

Tuan (1977) argues that visibility, both physical visibility (an object or feature) or in a more contemporary sense, symbols such as events and reputations, is key to the experience of a person's or a community's recognition of their place identity. Tuan emphasizes the centrality of these characteristics to their power of experience. In describing how a place's visibility is constructed by residents' perceptions as much as by outside propaganda (172), he evokes the notion that most geographic knowledge is rooted in ignorance. The everyday person knows only their immediate and practical environment 
that sustains them stating "our imagination constructs mythical geographies that may bear little or no relationship to reality" (86). He cites the peculiar tendency of American cities to hyperbolize obscure facts to achieve visibility in the age of frontier development, which has evolved into the "boosterism" of today's vital statistics of a city's identity.

Tuan's meditations on mythological space, visibility and experience opens up a more complex and nuanced debate on the factors, agents and circumstances which lead to these suppositions about a particular place. Harvey (1990) argues that the shift toward paradigms of post-modernity from of those of modernity (which dictated spatial structures and concepts though an elitist minority) have illuminated the existence of agents uncontrollable by the planners and engineers of efficiency. Citing Bachelard he quotes, "Space that has been seized upon by the imagination cannot remain indifferent space subject to the measures and estimates of the surveyor" (1964, xxxvi; Harvey, 1989, 217). Harvey's meta-critique - to be very brief - encompasses the spatial structures of capitalism specifically in the context of place identity, within a modernist paradigm, he emphasizes the difficulty in achieving a unified or "realized myth" given the agitated nature of spatialized social practice in a capitalist system. Place then struggles with the ever demanding constraints of space and time.

Massey (1994) asserts that place is largely controlled by time. The event of a specific moment that defines a place also serves to mythologize what is in reality a more complex storm of identities. The construction of place is inferred by the coincidental intersection of events in repetition over time. Events become familiar as social practices and are reinforced by spatial relationships of repetition (leaving home through the front 
door as opposed to the kitchen window). These relationships emerge as what Harvey refers to as "permanences" and are vulnerable to inevitable decay (1996, 261). Massey (1994) cautions readers about thinking of places as previously arranged and permanently fixed and invites us to identify a place with some sense of temporary-permanence in order to contain those very transitive interactions into a meaningful base from which people can react ${ }^{4}$.

Shields (1992) focuses on cultural marginalization and positional stratification as a means of constructing and retaining place identities through outside agents (such as tourists). Shields argues that a "place-myth" is mediated through spatialization. This is reflected in Massey's (2005) notion of places being co-constitutive where the meaning of a place is mediated through competing discourse.

Spatialized identities occur at many scales. National identities emerge with an aim of defining who is and who is not, while a local identity may seek to define what is or is not part of that identity. Shields (1992) discusses marginalization of a region for the benefit of a non-resident consumer class and captures Tuan's (1977) notion of visibility in the abstract sense: however, Tuan's focus is historical and primarily discusses the emergence of city-states as visible in the physical sense and less about a nation-state's abstract identities - particularly regarding mediated communications like film, music, or marketing. Edensor (2002) explains national identity as being mediated through agents of

\footnotetext{
${ }^{4}$ This discussion about Tuan, Harvey and Massey serve primarily to indicate the transition in academic perspectives within the realm of cultural geography. Harvey and Massey represent a shift from Tuan's humanistic approach into structural/post-structural perspectives. Considerable work has been published on this subject since. A synthesis of these ideas and their current status can be found in Murdoch (2006).
} 
popular culture and asserts that conceived notions of nationality - as prescribed by "highculture" guardians - are now more challenged by regional elements of vernacular culture. Edensor contends that place identity (whether regional or national) is predicated on the cultural performance of practices, traditions and ideological myths by the actors engaging that space. Performance then has the capacity to both overcome pre-conceived ideas or myths of place and to introduce or reinforce alternative identities yet still hold ground for established and stable systems.

The identification of what Park and Burgess refer to as "moral regions" is part of recognizing the divergent yet intrinsic qualities a "red-light district" or "vice-zone" has on the overall identity of a place $(1925,45)$. As such districts emerged, authorities typically corralled activity to within a narrow region in order to better direct where vice activity would occur. Ryder (2004) argues that these districts historically resided in areas near skid rows and immigrant communities/bohemian districts, not because these were easy populations to target, but because authorities were more tolerant of vice in these locations. Ryder's focus is on New York City's Times Square locale. He suggests that adult entertainment district's locational origins may be accidental but the emerging pattern of clustering became operable and sustainable. Their explosive increase during the 1970s was both a combination of relaxed moral codes and US Supreme Court rulings defending First Amendment issues. More conspicuously, however, was the decline in city center populations and economic decline of land values (particularly in New York). Adult entertainment became one the few businesses able to pay high rents. This offset the overall blight. Hubbard (2009) acknowledges the shift from tightly contained vice 
districts in both the U.S. and the U.K. as hubs of diverse sexual markets to diffuse growth almost exclusively in the form of strip clubs. This diffusion has disrupted the tacit acceptance of constrained spatial arrangements of discreet red-light districts and, in the U.K., has engaged a national debate on the nature of such entertainment.

Cresswell (1996) explains the relationship of place and ideology in the construction of moral codes. Codes may exist but remain hidden. Cresswell refers to this condition as doxa. Doxa is the position which allows for a particular ideology to maintain control; when awareness of an individual position arises, doxa dissolves and control is contested. This act of contestation leads to (or is) transgression by Cresswell's terms. For geographers, the role of transgression serves to demonstrate both the futility of certain existing boundaries and the recognition of previously absent boundaries.

Creswell (1996) suggests that critical geography be more directed toward "analysis of the role of geographic forces in the explanation of other things" and "the active constitution of places through cultural struggle" $(12,13)$. For Creswell this requires understanding the role ideology plays in the construction of meanings of places. For someone or something to be "in place" or "out of place" requires the awareness that such differences exist; Cresswell views ideology and a moral code as primary in making this distinction. 


\section{Historic Background}

\section{Origins of Burlesque and Striptease}

The circumstances that have enabled the current configuration and presence of Portland's adult entertainment establishments are as extensive as they are elusive.

Tracing the history of exotic dance and striptease in the U.S. requires a much deeper historical reach. This treatment is far from exhaustive and is only intended to understand the present condition of exotic dance in the U.S, and Portland.

The growth of striptease stems from the emergence of burlesque theatre in the late 1800s. The dance styles mimic orientalist perceptions of belly dance as it was imported from Middle Eastern and North African cultures and put on display at large events like the Parisian Exposition and the Chicago Columbian World's Fair (Allen, 1991, Jarrett, 1997). Throughout human history various forms of ancient dance have engaged ritual and ceremonial devices aimed at fertility. Such sacred and ritualized dances became secularized with the decline of empires like the Egyptian and Babylonian civilizations. This secularization of belly dance came to accommodate a formal association with prostitution in the form of private harems and traveling dance spectacles (Jarrett, 1997; Hanna, 2010).

The World's Fair expositions of the late 1800s introduced the belly dance as one of the many anthropological exhibits presented at these events. The "Street of Cairo" was then mimicked by many American dancers and became known as the cooch dance. According to Jarrett (1997) and Allen (1991) the acceptability of these dances resides in 
the distortion of Western ideals of prudent sexuality and an Orientalist liberated sexuality, which could now be confined and controlled within the borders of a local dancehall. The cooch dance greatly influenced the early burlesque shows, which gained prominence in tandem with the growth of Vaudeville in the 1800s. Originally burlesque parodied the political establishment and bucked the Victorian social norms through the voice of female performers who gestured with suggestive movements and bawdy language (Allen, 1991). Burlesque clubs became popular forms of alternative entertainment that tended to mock performances of more serious shows in nearby "legitimate" theatre (Jarrett, 1997).

While burlesque was considered "low-class" entertainment in contrast to the Broadway shows of New York City (much its audience were the single men of immigrant labor communities), it attracted more diverse audiences as the economy declined. This led to fiercer competition for musicals and symphonies. By the 1930s burlesque was more synonymous with striptease. As Broadway theatre owners sought to curtail the growth of burlesque, attempts at regulation ranged from questions of moral degradation to cultural ownership. A case arose leading to assertions by the Immigration and Naturalization Department to declare the striptease a uniquely American form of dance (New York Times, 1937). At the same time Mayor LaGuardia of New York had led a campaign against Burlesque and succeeded in closing almost every establishment. This remained in effect (officially) across the U.S. until after World War II.

The late 1940s and 50s saw renewed prosperity, and the emergence of the pin-up girl as a symbol of feminine beauty grew out of the propaganda campaigns of the war 
effort. Burlesque again gained popularity in larger cities in the form of the celebrity striptease. Names like Betty Page and Tempest Storm toured cities for extended stays, including Portland, throughout the 1950s and 60s (Jarrett, 1997; Stanford, 2002). Like the burlesque theater shows, these striptease shows occurred on a large stage with great distance from the audience which remained seated in rather formal arrangement compared to the strip shows of today. More remarkable was the degree of actual nudity in the old shows. The dancer performed an act lasting the length of song or monologue of sorts (5 minutes) which ended with a brief (10-15) seconds of nudity, usually only the breasts and rarely the full body.

Avant-garde performances of the 1950s became more recognized in cities like Paris. Performance art of this type incorporated public nudity more regularly and attempted to reframe the nude, specifically the female nude, as artistic spectacle. Jarrett (1997) notes that the Parisian avant-garde performers discovered American burlesque and sought to recreate it as a parody of the American Western fantasy. Nudity as spectacle became more commonplace in American night clubs other than burlesque theatres as an indirect result of Parisian avant-garde. Audience control between burlesque acts involved the employment of "Candy Butchers" who sold pornographic material between shows mostly to harass the audience and clear the seats for new audiences. These salesmen came to control much of burlesque and replaced much of the strip tease burlesque to a more raw form of exploitive stripping.

During this transformation in burlesque, dance clubs began featuring popular rock music and female fans seen dancing on tables were termed go-go dancers (and the clubs 
go-go clubs). Club owners quickly saw the opportunity for profitable entertainment and began hiring troupes of go-go dancers to entertain more passive patrons. This identity, however, between the dance clubs and the striptease theatre became more and more blurred, and the go-go dancer and the stripper became synonymous. Given the exploitive intentions of the candy butchers, the striptease declined largely into debauchery. Jarrett states:

In America as well as France, striptease became just stripping. Without the 'tease', many dancers found it difficult to portray their personality or to express their sexuality. A new range of services sprang up 'go-go dancing', photographic modeling for the pornographic industries and hostessing in night clubs - all of which were interchangeable options for girls working as strippers.

In Portland, Burlesque clubs like the Capitol and Star Theatres competed fiercely for the Saturday night audiences during the 1950s. Portland politics from that era have been well chronicled as highly corrupt, and the control organized crime had on the police department enabled a proliferation of prostitution (Stanford, 2002). The burlesque theatres reportedly operated independent of the crime syndicate but had to pay a price to stay open. When the scandal was publicized, most of Portland's political elite went before Congress. The resulting shake up in the political structure of the city led to a near total shutdown of all the city venues connected with prostitution and gambling including the Capitol and Star.

While the details are murky for Portland's nightclub scene during this era it has been noted that there was a thriving nightlife in areas now know as Old Town and the Eastside (Coleman, 2009; DeStefano, 2006). While the Star and Capitol Theatres 
experimented with nudity in the 1950s, smaller clubs in the 1960s, as in other cities, were testing the limits with go-go dancing. Mary's Club is recognized as Portland's first official strip club as it featured topless dancers for the first time in 1965 (Mary's Club, 2009). The legal boundary between "topless" "partial exposure" and "nude" seems unclear at the time, which enabled clubs to experiment. Typically clubs in unincorporated areas (near city limits) were unregulated regarding nudity.

\section{Oregon's Constitution and Portland Strip Clubs}

The legal history of free speech specific to nude dancing in Oregon emerges in the late 1960s. The U.S. Supreme Court has held that obscenity is not protected speech (Roth v. United States, 1957) but that obscenity (in brief) is determined by a test of community standards of decency. Challenges to the framing of obscenity laws regarding nudity and sexually explicit behavior in other state and federal courts had met with some success, as in California (In re Giannini, 1968). In the case of City of Portland v. Darrington (1969) the State Supreme Court overturned a lower court ruling declaring an anti-nude ordinance unconstitutional on grounds of free speech and vagueness and upheld the city ordinance, which prohibited exposure of a female's breasts. The regulation only pertained to establishments serving food and alcohol, and the charge did not involve obscenity but the violation of a health code. Two of seven justices dissented, finding the regulation as it was written to be a reasonable violation of a citizen's rights. Topless dancing was legal in a legitimate entertainment venue determined by the city council, but bars and taverns were also not permitted to have live music. The test to city regulations lies in the nebulous distinction among any of these establishments. Mary's Club was purchased as a 
licensed piano bar, hence under OLCC regulations it should not serve alcohol much less provide topless dancing. The Oregon State Courts and the Legislature volleyed numerous legal cases and revised statutes through the tumultuous ideological shift of the 1970s with no conclusive statement on constitutional precedent for adult entertainment until the mid 1980s (City Club of Portland, 2000).

While the introduction of Portland's regulations regarding nudity in bars and restaurants during the 1960s recognized the presence of such activity, enforcement appeared to lag. In Sekne v. City of Portland (1986) the restriction of nudity in bars was challenged with support from the Oregon State Court of Appeals. The Sekne case emerged as a result of Portland's numerous annexations eastward into Multnomah County. As taverns and pubs came under city jurisdiction, greater restriction over nudity led to confrontations. Sekne argued that his club, the Graffic Tavern, was illegally annexed and that the nudity ordinance was unconstitutional as other forms of nudity were permitted (Brenner, 1993). The court ruled in favor of Sekne on grounds that the ordinance was overbroad in its reach by restricting nudity more in one type of establishment over another.

As noted in State of Oregon v. Brooks (1976) nudity of any type was ruled permissible in a theatre setting because it does not occur in a public place as defined by the state obscenity statute. The statute defines a public place as that which someone enters at will. Since the theatre required paid entry, forbade minors and advertised the contents of the entertainment, the charges were overruled. Also addressed in the Sekne case was the Liquor Control Act which states no opinion on nudity, only forbids lewd 
behavior; it also states that it has primacy over municipal charters. While the court was not compelled to rule against the city on these grounds, later cases would revisit this stipulation.

In State of Oregon v. Henry (1987) the Oregon Supreme Court overturned a conviction of an adult bookstore owner in Redmond, Oregon with the historic conclusion that:

...Oregon's free speech protection, covering "any subject whatever," was broader than that of the U.S. Constitution as interpreted by the U.S. Supreme Court. The court reviewed the historical development of obscenity laws and concluded that restrictions on sexually explicit or obscene expressions were not well established at the time that its Constitution was adopted.

The Henry ruling not only nullified much of the regulatory language in the state and municipal statutes regarding nudity and pornographic material but added momentum to the exotic dance club scene. Attempts to fortify zoning ordinances were also hit by the rulings the following year in Tidyman $v$ City of Portland (1988) as zoning that targeted specific establishments was deemed overbroad and restrictive of free expression.

The Henry and Tidyman cases had worked their way through the system over the course of seven years. Previous lower court rulings left doubt about the enforceability of existing ordinances and theatre and club owners began expanding venue entertainment by 1984. The low feasibility of continued enforcement and court costs discouraged actions against new or annexed establishments. The legal victory for civil libertarians allowed for open promotion of existing clubs and, according to local politicians and journalists, proliferation of new businesses as well (Bella, 1989). 
In cities surrounding Portland, the emergence of nude dancing led to conflicts with local residents and city officials-- most of whom were unaware of the recent happening in the courts. Attempts at regulation stalled as empty threats. In 1989 the Oregon Legislature began debate on the issue. Initially the debate centered on crafting a model ordinance for cities to use that would meet a constitutional test, or whether to just amend the constitution. Most legislators and judges held strong reservations against tampering with the constitutional language, particularly regarding free expression (Mapes, 1989). Amendment Bills did pass the House, but died in Senate Judiciary Committees consistently through both 1989 and 1991 sessions.

\section{Oregon's “Anti-Porn” Ballot Measures and the Liquor Control Commission}

Measure 19 appeared on the November, 1994 ballot. Despite talk of a model ordinance by Attorney General Dave Frohnmayer and Senator Joyce Cohen nothing materialized. More strip clubs opened in the smaller cities like Hillsboro, Oak Grove and Gresham but also in Portland neighborhoods like Hollywood, Hosford-Abernathy, and Kenton. Some, however, did not open - a result of public pressure and locational constraints. Reports of the time vary widely but the number of clubs went from 12-18 up to 40-50 between 1987 to 1993 (Bella, 1989; Duin, 1993). Local zoning ordinances continued to pass - some blatantly barring nudity, others focused on secondary nuisances. But city officials were reluctant to apply them until the constitution was tested, an expensive process. Citizens of Gresham who had long protested the opening of a local strip club responded unsuccessfully in 1990 with a ballot initiative signature campaign (Blackmun, 1990, June 11). The same club (CJ's now Cabaret II) was featured in CBS's 
news show 48 Hours on obscenity (Oregonian, 1990, June 1). At the time the U.S. Supreme Court was poised to hear cases involving nude dancing and other free speech issues and Oregon typified the example for the media outlet. In 1991 the U.S. Supreme Court upheld Indiana's ban on nude dancing, but Oregon Legislators were still content to focus on nuisance laws (Rubenstein, 1991). By this time Portland was well recognized for its strip clubs. Radio hosts Mark and Brian, a nationally syndicated Los Angeles radio show, hailed the city's reputation during a remote broadcast in Portland (Shulberg, 1993, November 19). In 1993 a number of high profile crimes related to strip clubs occurred amid the Legislature's neutered wrangling over constitutionality in the latest bill amendment to the free speech clause. Representatives Kevin Mannix and Sharon Wylie pushed Measure 19 to the public (Brenner, 1993, September 23; Snell,1993, April 24).

Measure 19 focused on amending the constitution to stop child pornography, as a loophole regarding the legality of its possession had resulted from the 1987 Henry ruling, but included generalized language aimed at obscenity but intended for nude dancing. Measure 19 failed in spite of vociferous support from most legislators, opinion columnists, and social service advocates. Notable voices opposed it as well. Portland Mayor Bud Clark changed positions after consultation; the Oregonian Editorial staff spoke out against it, as did gubernatorial candidate John Kitzhaber. It is largely believed to have failed by such a large margin due to confusion in the wording (which conveyed the opposite message about child pornography) and also because of concerns over the fate of free speech given the vagueness of the measure. 
Oregon's legislative and judicial history with strip clubs and obscenity is intertwined with the regulatory position of the OLCC. Many policing methods were adopted by the OLCC to avoid constitutional/legislative dead ends. However, most of their attempts met similar legal challenges and fell short of satisfying the concern of residents opposed the proliferation of nude dancing businesses. The precedent set by the Henry (1897) ruling disabled the OLCC to consider entertainment content for license applications and could no longer take such recommendations from city councils. License denials had to be based on defined legal or public safety (not moral) criteria. The OLCC has a statute that prohibits lewd behavior in establishments that serve alcohol, but "lewd" is a vague term that does not include nudity or simply erotic expressions. In 1990 the OLCC experimented with distance rules for dancers/patrons to prevent unlawful touching but dropped them after eight months for similar constitutional reasons (Oregonian, 1990, June 5).

During the 1990s, the role of the OLCC in attempting to regulate the reported proliferation of the strip club industry became more pronounced. While a city council could not make recommendations to deny a liquor license based on performance of content, they could insist that an alcohol-related establishment be considered unsuitable due to existing area conditions - namely crime or other nuisances. During the Measure 19 campaign a move to open an upscale "gentleman's club" in Portland's Oldtown neighborhood was met with considerable opposition as this was a revitalizing area seeking a nightlife district. The club developers became operators of a well known chain of clubs across Oregon called Stars Cabaret. The OLCC successfully rejected the 
license application on the grounds that Oldtown was a problem area. The following decade three similar clubs would open in the same area. It does not appear that such criteria were successfully applied in any other license application regarding nude dancing establishments, though licenses were revoked due to problems surrounding existing clubs.

The Stars Cabaret operators abandoned Oldtown for Beaverton, and initiated what became a strip club trend relative in scale to Portland. Some strip clubs had opened previously in the region west of Portland with only moderate success, and a very outspoken opposition by residents. The Stars move represented something different since its location was not just a problem because of its proximity to schools or churches but was in the central business district of Beaverton, now a burgeoning Portland suburb, and trying to revive from an economic slump (MacKenzie, 1995, April 13). While the defeat of Measure 19 still echoed in the legislature, East Portland and smaller surrounding cities also saw more club openings, women's right groups rallied and marched along Sandy Boulevard ( a notorious hub of sexually-oriented business), and small protests erupted outside clubs and shops throughout the region (Bodine, 1996, June 17; Foden-Vencil, 1995, May 12; Oregonian, 1995, June 3) . Fears of adult entertainment incursions inspired the next obscenity initiative for the November 1996 ballot, Measure 31.

Like Measure 19, Measure 31 sought to amend the constitution to allow regulation of obscenity, affording no greater protection than allowed by the federal constitution's first amendment. Measure 19 failed by a near 9 percent marginreportedly due in part to confusion in the language of the statement and its summary. 
Proponents and opponents of Measure 31 believed it had a better chance of passing (Bates, 1995, March 20). Both Measures sought to include child pornography specifically in the Measure's language. It had been theorized prior to Measure 19 and confirmed in 1995 that child pornography could be interpreted as protected speech, however, this was due largely to technicalities in the legislative language of laws at the time and was remedied through statutory, not constitutional changes. Measure 31 failed by a margin of 5.6 percent, considerably less than Measure 19 (see Table 1).

Measure 87 appeared in the November 2000 election. Like Measures 19 and 31 it sought a constitutional amendment to allow regulation of the legal sex industry. Unlike the two previous measures, it adopted very narrow language focused on zoning of sexually-oriented business by local governments instead of the broad language that focused on obscenity. Support for the measure appeared to have increased among community activists as the zoning language made the constitutional intent more clear. The Oregonian had featured editorials opposing meddling with the constitution. While the editorial cannon maintained favor with the existing constitutional language opposing Measure 31, many opinion columnists did have strong attitudes against the proliferation of adult entertainment. One editorial supported referral of the House Resolution 52 to the voters as Measure 87 yet final election endorsements for the measure rejected it (Oregonian, 2000, October 23). Opposition for the measure came from previous opponents like booksellers, art galleries, and librarians but also from many legislators some of whom had supported (and forwarded) the previous bills and Measures 
19 and 31 . Measure 87 failed by a margin of 5.2 percent, only slightly less than Measure 31 (Table 1).

\section{The Liquor Control Commission and Oregon Courts Revisited}

The growth in strip clubs tapered off somewhat but Beaverton saw a continued expansion and some areas in Portland saw in-fill of added clubs (Figures 2). It should be noted that since the Sekne v Portland (1986) case the number of clubs in operation as reported by law enforcement/OLCC, sex industry representatives, and journalists in media articles varies widely from as few as 12 to as many as $100^{5}$.

Following the 2000 election both the OLCC and the courts re-entered the forum on strip clubs. The OLCC now faced growing concern about under age workers in alcohol establishments, as these workers included nude dancers. The OLCC had also better defined its criteria for lewd behavior, barring any dancer from touching themselves during a performance. Two unrelated cases also emerged involving an ordinance establishing distance rules for dancers and patrons in Nyssa, Oregon (on the Idaho border) and a live sex act between two dancers in Roseburg, Oregon (south of Eugene).

The OLCC rules on underage dancers and musicians had flexibility built in to accommodate the constitution and permit under age workers to fill other jobs as servers. The growing permissiveness and public discomfort with high school girls of adult age

\footnotetext{
${ }^{5}$ Much of the disparity in the counts of nude dance venues lies in the confusion over what is considered a strip club versus other adult establishment like massage parlors (officially extinct in Portland since 1993 [Green, 1993] ), private lingerie modeling- still protected, and peep shows- now very rare. Many reports may aggregate these venues together and other times not. The distinction between strip clubs and these other venues is discussed in much of the literature on exotic dance.
} 
dancing at drinking patrons' tables led to a number of hearings and a 2002 decision to ban all minors (under the age of 21) from working in alcohol establishments, with exceptions given on special requests (Boule, 2001, March 18; Har, 2002, August 16). Challenges by musicians and other performers to the age rules followed, as did lawsuits from clubs fined over the lewdness standards. Pending results from the Court of Appeals over the Nyssa and Roseburg cases kept the OLCC and law enforcement agencies on unsure footing.

It is important to understand the specificity of the State Supreme Court rulings on Henry (1987) and Tidyman (1988). Neither of these cases specifically ruled on nude dancing, only pornographic images. While the Court of Appeals ruled in Sekne (1986) about nude dancing, the focus was on whether a licensed alcohol establishment could feature nude dancing, as such entertainment already existed in non-alcohol establishments within Portland's and other city limits and was performed presumably in some cases by adult persons under 21. The Court of Appeals favored both the Nyssa ordinance and the Roseburg prosecution, ruling against the defense of live sex shows on existing grounds of lewdness and ruled against the defense of current nude dancing standards in the case of Nyssa's proximity limits for dancers. Because the State Supreme Court had never ruled specifically on nude dancing but instead only on the broader concept of obscenity, no challenge to precedent existed on those terms. However, the challenge was present in the interpretation of historical exception, a complicated legal tool meant to explain what was meant by those who crafted the constitutional documents guiding all of these decisions. In these two cases the Court of Appeals used historical 
exception much differently then the Supreme Court of 1987. The State Supreme Court of 2003 chose unequivocally to hear both cases.

In 2005 the Supreme Court ruled against the charges imposed on both strip clubs, upholding the present interpretation of free expression in Oregon by a near unanimous decision (5-1). The Court did however uphold the conviction of the Roseburg club owner on charges of promoting prostitution because of his profiting from the live sex show. Experts believed these decisions strengthened Oregon's free speech precedents but also set up future conflicts regarding the prostitution conviction (Green, 2005). The bar for what was considered lewd or beyond expressive was now set very high. This left the OLCC with little enforcement power over club entertainment content and gave municipalities little guidance on what was governable regarding private nudity.

\section{Controversy Persists}

The debate over the place adult entertainment, particularly strip clubs, has in Portland and all of Oregon was (and is) far from over. While the OLCC grappled with how to enforce existing laws of illegal conduct, the opening of more clubs stirred similar community reactions. In 2008 the Stars chain of gentlemen's clubs sought to open a club near an interstate highway exit in Tualatin, a Portland suburb. The response from local residents was much the same as the rhetoric reported in similar cases of cities like Portland, Gresham, Oak Grove, Milwaukie, Wilsonville, Beaverton, Hillsboro and other towns across Oregon: This is an inappropriate place for that kind of activity (Bella, 2008). And as in previous episodes, the residents were encouraged to participate in the 
hearing process only to be told that such a business could not be judged by it content (Croy, 2009). Tualatin residents and administrators - apparently unaware of the continued media coverage, the case law and ballot measure history, and the struggle of other communities similar to their own - were dismayed to hear that they had no say in what type of business could operate in their commercial corridor.

Stars was granted its license. Tualatin residents vowed to carry their cause to the legislature, which they did. Constitutional amendments were debated in the House committee but went nowhere (Schmidt, 2009). In 2008 Kevin Mannix,, former state legislator and co-sponsor of Measures 19, 31, and 87 - now a lobbyist, dropped an attempt at a voter ballot initiative aimed specifically at nude dancing because of lack of signatures and financial support (Law, 2008). Between the 2008 Stars opening and the end of 2010, one club has closed (the result of a Portland Development Commission purchase) and four more strip clubs have opened in Portland, two in the downtown business core and two in neighborhoods with an historical familiarity and discomfort with their presence. 


\section{General Discussion}

To better understand how strip clubs contribute to the identity of Portland (or any other place), the significant literature, findings from the analysis, and unaddressed assumptions need to be sorted out and discussed. First, the "dance" itself is considered as it relates to the immediate exchange between dancer and patron, the social and spatial structures that establish the exchange, and the agency devices employed to negotiate identities between dancer and patron. Second, the primary constituents are considered in "relational space" regarding their position in the network of social and spatial practices as they relate to formation of places (strip clubs) from spaces. General patterns associated with Portland strip clubs are considered. Third, the cultural performance of social/spatial practices as they migrate from transgressive to normative and how place identity (specifically in Portland) becomes negotiated by this performance.

Exotic dance is described in general terms, summarizing contributing literature. Relational space describes networks of practices in general terms but examines actors in this network unique to Portland. Place identity is discussed specific to Portland's performativity of transgression through strip club proliferation ${ }^{6}$.

\footnotetext{
${ }^{6}$ A document of human subjects for this research proved overly challenging for the scope of work undertaken. Many observations were made of clubs in the context of landscape setting, club activity -both indoor and outdoor, and of individual opinions of attitudes of strip clubs. These observations are presented only as anecdotal and not part of any reviewed subject analysis.
} 


\section{Exotic Dance in the Context of the Strip Club Setting}

Strip clubs are gendered environments. Whether the dancer is male, female, or transgender the motivation of the dancer and patron is to engage in some form of observation, celebration, or objectification (academically the most salient act) of the dancer-- specifically some distinguishing quality like aesthetics, talent, or extreme spectacle. Aesthetics might typically insinuate the overall attractiveness based on majority standards, but also include unique traits like muscularity, maturity or ethnicity. Talent may include the dancer's general personality or the specific use of devices like burlesque (increasingly common both within and outside of clubs), pole dancing, and other props like fire. Extreme spectacle involves the use of the genitals as the primary object of engagement.

The most common activity in a strip club is a female dancer engaging a proportionally high male patronage. A dancer's job in this sense requires her labor to fulfill the male (and perhaps female) expectations of gendered sexual roles, with men acting as financial providers and women as sexually emotional providers though not truly sexual gratifiers (Bruckert, 2002; Egan 2006; Uebel, 2004). This oversimplifies the dynamics of the interactions with dancers, but serves as focal point to critique the more nuanced variations of strip club activity. The male patron seeks not the fulfillment of desire nor absolute domination over women but the mitigation of pleasure, as Uebel states "defending against the possibility of pleasure becoming unpleasure" $(2004,11)$. Here Uebel's patron seeks refuge from the legacy of patriarchal systems by immersing himself in the very epitome of what symbolizes that legacy, but masochistically subverts 
his desire (or sometimes violence) into subservience to the dancer and the fantasy of being desirable for his masculinity.

It is wholly uncritical to project the dancer as objectified/victim and the patron as objectifier/victimizer and vise versa (Egan and Frank, 2005). Dancers of all gender types find themselves on the stage in both a position of power and confinement; for as their nudity provokes an intoxication, it is dependent upon the positionality of their visual dominance. Egan acknowledges that women exotic dancers "occupy a unique position in that their bodies are sought out in the market as objects of desire and, as such, it is their job to recognize men and make them feel desired and desirable" $(2003,112)$. The patron's position resides in a more questionably subservient situation. Their financial obligation to tip the dancer and the loosely enforced rules on touching a dancer contrast with notions of the dancer's financial dependence on tips and emotional dependence on a patron's enthusiasm (Barton, 2002; Brewster, 2003; Egan 2003 and 2006; Frank, 1998 and 2002; Lewis, 2006; Murphy, 2003; Trautner, 2005; Uebel, 2004).

Egan further asserts a dancer's agency in constructing the specific direction of her objectification:

"Unlike other forms of commodified eroticism, such as print or videographic pornography, dancers in their personal interactions are more than simply screens for men's projections. They invoke resistances and disrupt the recursivity of power within the matrix of fantasy and desire through their actions and reactions. They move within and between subject and object on a regular basis and invoke strategies of covert mimesis within the club" $(2003,115)$.

So while the patron has power in both the immediate monetary exchange and the historical structures of patriarchy, the dancer (according to Egan) has both the weakness 
of the patron's desires and her own tools of provocation to manipulate the subject-object dialectic. But while dancers may secure power over patrons within the club, that identity is fragile and temporary and - as Uebel points out - male submission "is almost never a political alignment with femininity" $(2004,15)$.

Other actors influence the immediate exchange between dancer and patron as bar staff and DJ's alike encourage tipping. Change is always given in single bills, speakers and signs announce the requirement to tip, while staff members continually direct patron's attention to the stage. Dancers are equally reciprocal as they encourage further consumption from the bar (Lewis, 2006). A typological exception to that is acutely described by Bradley-Engen and Ulmer (2009) as the hustle club, where patrons subscribe a menu of activities promoted by the dancers. Dancers are compensated on commission for the activities they sell. Dancers' stage time is controlled by the DJ, who in almost all club environments wields some control of a dancer's activity, and he typically exacts some form of compensation from the dancers while enforcing codes of attitude.

Each of these spheres of activity is situated by their spatial arrangements in the club. Frank states that "Visibility is also related to the formation and maintenance of social power and is implicated in spatial relationships, especially through the distinction between public and private space" and further states "strip clubs come to have the power to make experience meaningful ... through their inner geographies, through strategies of spatial organization and representation" $(2002,59)$. Egan also points to what she calls the "social cartography" (2006, 19 and 39) of the clubs internal arrangement drawing on 
its security and surveillance systems that give club operators visual access to every part of the space.

The means of social control of performance through spatial organization serves the club owners/managers in maintaining financial success. This is achieved by negotiating two opposing economic forces: first, an atmosphere where patron expectations are met in such a way as to keep the business successful (by spending money) and two, that dancer and patron behavior is maintained so as to stay within the boundaries of the law and any other social codes developed between dancers and managers ${ }^{7}$.

\section{Relational Space as Social and Spatial Practice}

Every event that occurs in a strip club, as anywhere else, does so with an infinite number of events preceding it. These events result from processes constrained by constantly developing networks of actors who intersect repetitiously over time. This repetition contributes to the formation of social practice and sense of place (Massey, 1994). The actor networks change while the recognition of the event as it originally developed reinforces the relationships of the particular social practice in reference to Harvey’s idea of permanence (1996).

\footnotetext{
${ }^{7}$ A major case taken on by the OLCC involved the engagement of lewd behavior by a dancer at The Bank (Office of Administrative Hearings a and b, 2008). Most significant to the case was whether the owner/operator of the venue was responsible for the dancers behavior since the dancer operated as an independent contractor highlighting another aspect of exotic dance, which is the role of labor classification. The case also began the long challenged discretion the OLCC held over the definition of lewd behavior.
} 
Practices and relationships as they culminate in the identity of a strip club, from the usually coercive design of the interior spaces to the scripted and non-scripted performances of dancer and patron, compose a multiplicity of transitory interactions and power dynamics of both consensual and contested processes. This condition constitutes what Murdoch describes as relational space that is "a 'power-filled' space in which some alignments come to dominate, at least for a period of time, while others come to be dominated" $(2006,20)$. The condition of relational space is dependent on the always evolving networks of actors, entities and resources that comprise the constituents. The networks of the strip club setting derive from a panopoly of constituents:

- The dancer's relations with other dancers and their conduct with patrons.

- The dancer's social life within the club with staff and management

- The dancer's private life outside the club.

- The patron's actions with dancers and their interaction with other patrons and staff

- The patron's own relationship outside the clubs both at work and home.

- The club itself and position in the landscape

- How conspicuous the club activities are and how they are perceived by surrounding businesses and residents

- The way position and perception interact with the activities of both.

- Advertising vehicles usually in the form of print and web-based trade publication, like Portland's Exotica ${ }^{8}$, have a distributorship beyond entertainment venues in order to reach the casual and tourist patrons.

- Many dancers work in numerous venues, some work in multiple clubs each day.

Patrons range from curiosity seekers to occasionals and regulars. Most are male, and engage with the dancers' performances on a continuum from casual observers to active

\footnotetext{
${ }^{8}$ Exotica magazine functions the as the only consistent adult industry trade publication in Portland, primarily promoting strip clubs and the culture surrounding them. Prior to Exotica the $T \& A$ Times held this distinction in the 1980s and early 90s. Other competing publications included SFX, Excitement (a spinoff of the national chain Xitement), and Baron. (Busse, 2003; Budnick, 2004)
} 
participants. Performances range from simple stage dancing to table dancing to lap dancing (both public and private), each with increasing scales of intimacy and proximity to the patron. Club owners, managers, bouncers, DJs and bar staff work to facilitate the dancer and are typically paid employees, while dancers typically work on contract and pay a fee to club owners to use the stage. In Oregon, local agencies rarely get involved with regulation of clubs as all the activity is now regulated under state jurisdiction. The primary state agencies are the Departments of Health and Revenue and the Liquor Control Commission (OLCC). Because clubs rely on their liquor licenses so strongly for their success the OLCC has historically played a large role in the opening and closing of strip club establishments.

Taken as a whole these constituents comprise a landscape of social and spatial practices where the actors can be highly transitive and the intersections are highly stationary. Many dancers and patrons alike have short or intermittent tenures in the industry and few display a commitment to any particular club (Bradley-Engen and Ulmer, 2009) ${ }^{9}$. Clubs, however, are more fixed (or stuck in many cases) by legal restrictions (Oregon being an exception) and basic market constraints, those that make scarce the facilities (club on street corner with lots of parking) that accommodate the specific needs of the venue and have an optimal location for patron accessibility. It is the very contrast of these constituents' practice that gives them their multiplicit identity,

\footnotetext{
${ }^{9}$ Bradley-Engen and Ulmer develop a complex typology of dancers and clubs presenting patterns of behavior and perceptions based on the social organization of each club. The three main club types include: the social club, the show club and the hustle club - each one progressively more competitive, controlling, profitable and restrictive on alcohol use. Conversely each club was respectively less desirable to work in and less likely to have regular customers $(2009,38-40)$.
} 
which in Massey's words is “co-constitutive” $(1998,29)$. In other words, strip clubs cannot be perceived or imagined as they are without the permanence proscribed by the social and spatial practices. The transitive nature of dancers and patrons against the "fixed" nature of clubs establishes a system where dancers and patrons can easily locate their practice, and clubs, presumably because of a seemingly inexhaustible supply, can expect a generally turbid flow of human capital.

\section{Place Identity and Portland's Strip Club Culture}

Strip clubs are present in almost every commercially accessible area of Portland. "It's much more okay, ethically and morally, to visit a strip club in Portland than it would be anywhere else" (Davis, 2006) ${ }^{10}$. The condition of Portland as strip club capital develops from the interjection of contested facts into the public consciousness as social practices inherent in the strip club have permeated from the transgressive realms into the everyday normative realms.

Viva Las Vegas’ 2009 memoir Magic Gardens portrays Portland at the end of the 1990s as a city in upheaval against a tide of empowered sex workers and Rock 'n Roll divas. In Viva Las Vegas' Portland, stripping was an intellectual trump card among the counter-culturally elite and a necessary credential for anyone claiming membership in the

\footnotetext{
${ }^{10}$ Davis, a recent transplant to Portland working for the Portland Mercury, offered this summary based on a general survey of friends and co-workers.
} 
new feminism of the time. Cabaret shows featuring strippers complimented a thriving arts scene and strip clubs sheltered artist like herself from boredom and economic hardship.

Working in parts of town much less gritty today she invokes a love affair with Portland's shadier reputation. Vegas chooses a decidedly limited and incomplete geographic embrace, working regularly at one club only and rarely acknowledging that much exists in the city beyond the neighborhoods north of West Burnside Street. Viva Las Vegas' memoir is important because it represents a popularized, albeit naïve, attitude of Portland's strip-club culture.

Las Vegas' is unwavering in here belief and logic that "stripping is art" (2009, p. 109). She spends very little time discussing the nature of Portland's condition as the "strip club capital", remarking briefly and uncritically on the per capita factoid and the Oregon Constitution. Yet it is her art that is the focal point of the constitutional controversy and what brings the general public to know that a free speech clause even exists at a state level of government.

Judge Hans Linde, whose scholarly legal thinking brought forth the current interpretation of Oregon's free speech clause, saw states as having limited themselves in their power to assert the unique values of their own constitutions (Epps, 2003). He found that Article I:8 gave much broader guarantees of expressive rights than the federal constitution's first amendment. Subsequent rulings by Linde based on Oregon, not U.S, constitutional precedents led to the decision in the Henry (1987) case where then Justice Robert Jones stated "In this state, any person can write, print, read, say, show or sell 
anything to a consenting adult, even though that expression may be generally or universally considered obscene.” (O’Hagen, 2000).

The continued support for the present interpretation, both in the courts and at the ballot box, can be seen as construction of a unique identity through reinforcement of an idealized notion of free speech where sexual expression in all its forms functions to exemplify the identity of Portland, and Oregon, as independently minded (if not obstinate) and offers a cultural stage specifically for Portland to showcase its iconoclasm. That stage exhibited the definition of Portland's willingness to accept the detractions of the sex industry in exchange for the distinction as hyper-tolerant and even perpetually carnivalesque in its embrace of free expression. "Combining political and social radicalism with sexual radicalism is a classic model" according to historian Robert Nye (as quoted by Carlin, 2010) going on to say that "people try to change the norms, the problem for straight laced people is that combining all that radicalism seems daunting and strange and hard to understand" implying that our recent constitutional history has brought not only our burgeoning sex industry but "iconoclasts, radical and other free thinkers" to the state (Carlin, 2010). Carlin suggests that while the seamier side of the sex industry has found a safe haven in Portland, it has also spawned an oasis for a more adventurous sexual culture apparent in the emergence of swingers clubs, fetish festivals, and the number of authors focused on sexual exploration.

During the 1990s, the opening of strip clubs, the public reaction to them and the ballot measures seeking to resolve them cultivated a political contest of ideology in construction since the Sekne (1986) trial. While Portland, functioning as a metropolitan 
cultural entity, supported free speech apparently with growing passion, the periphery of Portland and the rest of the state appeared less enthusiastic. Voting results of the 1996 and 2000 election demonstrate this. Though votes on the amendments are not a solid referendum on strip clubs or the sex industry, "yes" votes were a demonstration against the industry (Figures 5 and 6). The lack of yes votes in the core population centers of Portland where large concentrations of strip clubs resided could imply that acceptance came from familiarity (or complacency). Figure 1 shows that the ratio of yes votes (termed "anti-porn") to no votes (termed "pro free speech") increases with more distance from a strip club, however, voters closest to a club are much harder to discern regarding yes/no concentrations. ${ }^{11}$

As noted in the historical and legal background each ballot Measure failed by a smaller margin each subsequent year (Table 1, 1994 8.5 percent, 19965.6 percent, 2000 5.2 percent) yet the ratio of votes shifted toward the no vote (pro free speech) in the Portland metro region. Also of interest is the high number of yes votes in closest proximity to clubs in 1996 (Measure 31) visibly different in 2000 (Measure 87). This could be a result of clubs closing or relocating between 1996 and 2000. Four appear to have done so and there were 48 clubs present in the analysis of 1996 versus 45 clubs in 2000.

Another more general shift is present in a comparison of the three counties that make up the Portland metro region: Multnomah, Clackamas, and Washington. Again

\footnotetext{
${ }^{11}$ See Methodology Statement
} 
while the overall margin of votes in the state decreased voters in all three counties moved in the opposite direction (Table 2).

Shields (1992) argues in Places on the Margin that "place-myth" is mediated through "pre-constructed cultural discourses about sites" and the discourses occurring among groups of sites as part of his explanation of the spatialisation concept (31). The political dialogue exhibited by the three voter initiatives of the 1990s, where Portland held considerable sway in the election results, demonstrates a spatializing process of “antithetical place-myth" creation. Shields states:

Through a process of labeling, sites and zones associated with particular activities become characterized as being appropriate for exactly those type of activities. Other activities are excluded, forced into wilderness or barren spaces 'outside' of civilized realm, or they are associated with their own dichotomous spaces.

(1992, p.60)

Shields proposes a shuffling realm of images of any given site and these images are mutable and transitory. In the case of Portland (and beyond) these activities (stripping) were no longer subject to a moral code or a spatial code. However, a prevailing social code may have still acted as a determinate of the locations, offering discretion and quick access - in this case under-populated commercial districts near major arterial roads (Figure 3). Shields further elaborates on the constant yet evolving place-myth model: "core images change over time, are displaced by radical changes in the nature of a place, and as various images simply lose their connotative power, becoming 'dead metaphors', while others are invented, disseminated, and become accepted in common parlance." $(1992,61)$. The forces in opposition to adult entertainment fought to energize public 
opinion against the allowance of what appeared as demoralizing activity thereby projecting an image imbued with modesty and continence. Yet, the continued defeat of the "anti-porn" ballot measures, and the increased visibility of strip clubs (perpetuated by print media and the internet) had the reverse effect of portraying Portland oppositionally as both a "smut capital" and a free-speech mecca. During the ballot measure process many players contributed to the fight against changing the Constitution's free speech clause. Namely the Oregonian Editorial Board, Oregon Library Association, bookstore owners like Michael Powell, arts council organizations, and the American Civil Liberties Union (Oregon Secretary of State, 2000; Oregon Secretary of State, 1996).

Perhaps unlike Shields' "dirty weekend getaway" of Brighton, UK, where the myths of a sex-capade permeated the image of the city despite many other underlying images obscured by its reputation, Portland took on this reputation alongside other popular and less controversial economic statistics like coffee, beer consumption and library book circulation (Marthens, 2009). Here Portland has not necessarily succumbed to one mythologized identity but has embraced, with or without city council approval, multiple identities with many results, for example the opening of a the first vegan friendly "all flesh, no meat" strip club (Hogan, 2008). This shift in perspective views space, like culture, as unbounded in terms of strict place distinctions.

While definitions of obscenity and conflicts over sexual expression have persisted, historically the growth of adult entertainment resulted from changing paradigms in the Supreme Courts and cultural demands for greater tolerance of deviance. The existence of the vice districts in the past gave authorities the ability to control 
unwanted behavior and moral and social reformers a contained target for their agendas. The migration or expansion of these districts, by Ryder's (2004) account, suggests an economic trend driven by the need to follow the intersection of population traffic Measured against the dependency on relatively cheap land values to exploit. By the late 1980s, with more tolerant interpretations of the First Amendment, economic shifts out of recession, and greater accessibility to non-centralized markets, the spread of adult entertainment, particularly strip clubs, into the less marginal and suburban regions engaged a sector of the public traditionally unaffected by presence of the sex industry. This represented what Cresswell (1996) terms "out of place" as adult entertainment was transgressing upon the established geographic order.

While it must be considered that within the sex industry contests persist over what is or is not appropriate behavior, because of the social stigmas and the historical grouping of these entities (strip clubs, adult theaters/bookstores, peepshows) by police authorities into similar categories they have acted traditionally as a reasonably unified spatial entity. Transgression can demonstrate both the futility of certain existing boundaries and the recognition of previously absent boundaries (Cresswell, 1996). In the case of Oregon law the moral code against obscenity was undermined by a moral code of free speech and spatial codes were simply nullified from an enforcement perspective. Creswell states: “Transgressions appear to be 'against nature'; they disrupt the patterns and processes of normality and offend the subtle myths of consensus" (26). The interpretations by the Oregon State Courts since the Sekne (1986) case to the Ciancanelli (2005) and the three ballot Measures on obscenity indicate that regardless of public concern about the moral 
viability of strip clubs and nude dancing, they have a place in the cultural (and political) complexity of the state.

Here transgression contributes to the performance of culture as communities struggle with the emergence of previously unaccepted practices (strip clubs/adult entertainment) controlled by a moral orthodoxy (community standards/legislative elitism) now controlled by a legal and cultural orthodoxy (voter majority/judicial elitism). The court rulings in the Sekne (1986), Henry (1987), and Tidyman (1988) cases accelerated a fledgling sex industry. This in turn engaged combative community activists but also attracted and more intensely legitimized a generation of sexual adventurism. This is not necessarily directly connected to strip clubs or pornography but as Carlin (2010) argues, is part of the culture of sexual tolerance. As each ballot measure came and went the state became more divided. Even as the margin of difference in voting statewide drew closer voter resistance to changing the constitution in the Portland area grew apparently larger. Rural counties that seemed more divided in early ballot Measures (possibly due to low voter turnout) came out strongly in favor of Measure 87 - recognizably so in areas where a strip club had recently opened like Malheur and Douglas Counties.

Even as the 2005 court rulings reaffirmed the official position on obscenity, nudity and sexual expression, communities are still blindsided by the opening of a strip club and startled to discover they have little recourse in challenging its presence as was most recently demonstrated in the Tualatin Stars Cabaret case (Clampet, 2008; Schmidt, 2009) an the Mynt Club in the Laurelhurst neighborhood in NE Portland (Dimatteo, 2010). While the closure of the $92^{\text {nd }}$ St. Club in the Lents neighborhood of Portland was 
celebrated by urban renewal activists (the closure was facilitated by a Portland Development Commission purchase), within a year a nearby club at $122^{\text {nd }}$ and SE Holgate reopened as Heat capitalizing on its history as a popular strip club in the 1990s. Though the success rate of most clubs may be supported at some level by tourism given the proximity to the airport and Interstate 5 and 205, the wide dispersal of clubs into so many suburban areas like Beaverton and East Portland suggest something more than just a red-light tourist district. The continued reporting on and advertisement of strip club activities by local alternative weekly newspapers like the Portland Mercury and the Willamette Week - even the relatively conservative paper the Portland Tribune has advertised the Tualatin Stars Cabaret in their sports section- not to mention the popular distribution of the strip club trade publication Exotica - infer a strong local market for exotic/nude dance. As the new operator of the club Mynt states: "For the neighbors who don't like me, I hate to say it—-there's probably a lot who will like us" (Dimatteo, 2010).

No official data exists to determine how much support a club receives from a local economy but anecdotal evidence gathered from club visits lends credibility to this. The popularity of pole dancing studios for non-stripper clientele also supports at least the idea that most cities with a visible strip club presence are game for participating in it. In Portland one such studio, Becoming Juicy (now closed), not only taught pole dancing but also sponsored a stripper amateur night at the popular Devil's Point $\mathrm{Club}^{12}$ in SE

\footnotetext{
${ }^{12}$ The owner/operator of Becoming Juicy, Isis Leeor, promoted the amateur night at Devil's Point as part of a more extensive therapy regimen, which included pole dancing lessons but also course work in sexual issues related to women's (and men's) self esteem. The closure of her studio appears to be the result of a move to Seattle Washington.
} 
Portland, encouraging pole dance students to participate (Skinner, 2007). Viva Las Vegas' (2009) account suggests that a steady patronage by a local clientele is the backbone of the industry for Portland. Teresa Dulce, former stripper/sex worker and health advocate, thinks there is a unique support for strippers in Portland and Oregon that stems from the arts but extends to the general public (Drake, 2000).

The image of a vibrant stripper/sex-positive culture serves to define Portland more in contrast to the rest of Oregon more that to other U.S. cities. While Portland carries the "strip club capital" distinction, based on conflicting and continued media reports $^{13}$, many cities have comparable numbers of clubs, yet statistical results derive from the adult industry itself with no data provided to back them up (Mirk, 2009). More recent national reports have portrayed Portland as overwhelmed by the sex industry to absurd proportions with CBS impossibly identifying over 100 "strip clubs" on Portland's $82^{\text {nd }}$ Avenue (Oregonian, 2011). In reality the image may not be as solid for those who embrace it would like.

While the adult entertainment industry does maintain marketing data for all industry segments this proprietary data is not directly available and like most marketing data can only be purchased with limits on detail. Regardless of proprietary restrictions the internet is filled with sites listing club locations city-by-city with venue details. Each site list is typically inconsistent when compared to another. Comparing these lists to a

\footnotetext{
${ }^{13}$ As of 2009 it has been reported that Oregon is out ranked by West Virginia as the state with more strip clubs per capita, however most of Virginia clubs are located in close proximity to the Virginia State border. The same report challenges Portland's status in comparison to a number of significantly smaller towns in Oregon (Mirk, 2009). The argument then descends into methodological questions of what places should or should not be considered in this analysis.
} 
validated club list for the Portland area, used in the voter analysis above, numerous errors of omission and commission can be observed. Clubs are reported that have not been open for many years and others that are not really strip-clubs by definition but instead lingerie modeling or peep-show studios. Given the variety of restrictions on adult entertainment from state-to-state and by municipality it is difficult to uniformly define these venues' activity.

Using the internet data results and comparing club counts against a particular population geography provides some insight into the place myth problem. The difficulty in determining, not just what city or place has the most strip clubs (or any other notable artifact), but how the geographic measurement of places differs between political units (states, counties, cities) and the ways a local population perceives their place. Incorporated city limits are only one way to observe a place's distinction. Metropolitan units of measure also provide a more composite view of regional distinction and when discussing economic and cultural phenomena are more appropriate, assuming that a high level of interaction exists between the municipal entities.

Perception also plays in to the understanding of whether a club is part of certain place. Many club listings are addressed within cities whose jurisdiction they do not physically reside. ${ }^{14}$ Many clubs attributed to cities may exist in more rural areas or simply dot the fringes of the administrative unit. People observing these clubs from the

\footnotetext{
${ }^{14}$ When a ZIP code resides outside of an incorporated city it is given the name of the largest near-by city.
} 
ground, in a map, or media story are likely to place these clubs with varying geographic associations.

Observing data from two internet sites (Strip Club Database, 2008; The Ultimate Strip Club List, 2010) demonstrates the variability in reporting accuracy. The 2008 Strip Club Database list reports Portland with 24 clubs compared to the valid Portland list reporting 54 clubs in 2008. The 2010 The Ultimate Strip Club List reports 56 clubs (seven of these are lingerie/peepshow studios and two are closed) compared to the valid Portland list reporting 56 clubs in 2010. The ranking of CDPs (all cities) for 2008 is available (Table 6). The large discrepancy between the validated Portland club list and the 2008 Strip Club Database makes using this data for any further analysis unproductive, therefore only the 2010 The Ultimate Strip Club List data were compared against the populations of Census Designated Places (CDPs), Urbanized Areas (UAs) and Metropolitan Statistical Areas (MSAs - combined regional counties). ${ }^{15}$ To avoid misrepresenting clubs by their listed address city they were instead geocoded to their specific location and then spatially aggregated to each geographic unit using ESRI's ArcGIS software.

When comparing data many smaller population areas are included and rank high. This dilutes the intentions of the observation since a small number of clubs in a low population area pushes the per capita ratio well above any of the more familiar city

\footnotetext{
${ }^{15}$ Census geography differs from local administrative boundaries both in accuracy and methodology (U.S. Census Bureau, 2010). For purposes of this analysis the Census geography provided the most uniform boundaries of measurement.
} 
names. ${ }^{16}$ For that reason Tables 6-9 are selected using the 100 most populous units. Tables 10 and 11 show the rankings based on the entire list. Each table lists only the top ten rankings and the original ranking from the entire list.

Portland ranks very high among all three levels of geography. As a city (CDP) it ranks first with 9.59 clubs per 100,000 persons, as a UA and a MSA it ranks second with 3.74 and 3.1 clubs per 100,000 persons respectively. Other regions that rank consistently between all three geographies are Akron (Ohio), Tampa (Florida), and New Orleans (Louisiana). Akron ranks third among cities and first among UAs and MSAs.

Jacksonville and Palm Bay (Florida), Honolulu (Hawaii), Youngstown (Ohio) and El Paso (Texas) rank consistently between the UAs and MSAs. Among cites Atlanta, Miami, and Las Vegas ranked in the top ten but did not in the UA or MSA level. Missing from the list were Houston (which has the most clubs by count) and Los Angeles; both have large municipal areas and vast regional populations. They are ranked at $18^{\text {th }}$ and $77^{\text {th }}$ for cities, $27^{\text {th }}$ and $54^{\text {th }}$ for UAs, and $27^{\text {th }}$ and $49^{\text {th }}$ for MSAs. While Las Vegas ranked ninth in the city list, San Francisco was ranked $45^{\text {th }}$ and much lower in the UA and MSA regions. It has been common to cite these two cities as viable comparisons in previous print media (Mirk, 2009; Moore, 2005) as obvious rivals for most strip-clubsper-capita.

Portland's ranking as second in the UA and MSA category is interesting given that the population includes Vancouver, Washington located north of the Columbia

\footnotetext{
${ }^{16}$ Mustang, Texas ranks first among all CDPs with one club and a population of 21; when only comparing all incorporated cities Hammer, Idaho ranks first with two clubs and a population of 48.
} 
River, which has no clubs (Washington State, like most states, is far more restrictive regarding nudity and alcohol). In the rankings of the entire UA and MSA populations, Akron still ranks among the top ten, while Portland ranked $10^{\text {th }}$ among the UAs and $11^{\text {th }}$ for MSAs (Tables 10 and 11). Also present in these rankings are Myrtle Beach (South Carolina), Atlantic City (New Jersey) and Fort Walton Beach (Florida), all relatively small resort towns and other anomalies like Kokomo (Indiana).

The Census Bureau geographic units raise some questions about what makes the most effective and consistent description of place for statistical measurements. Including Vancouver into the Urbanized Area of Portland may be confounding, perhaps more so than including Sharon, Pennsylvania into Youngstown, Ohio, but these relationships exist through observed economic patterns. Strip-club culture is not exclusively local; it would appear that in many regions, like the beach resorts of Myrtle Beach and Atlantic City, they are mostly a tourist entity. For purposes of regional identity using the Urbanized Areas reflects a region that excludes rural population (even if they are within the administrative boundaries) and includes other municipalities that have economic reciprocity, which may or may not include strip clubs.

The per capita measures have some slim margins only because the club lists' data are so inconsistent. Any of these lists could be incorrect by as many as eight or more clubs for the larger cities, which would change the rankings significantly. Regardless of the data's accuracy is the way the media and policy makers view the subject. A club is simply a point on a map or a building on the street. While Las Vegas doesn't rank as high as some might expect one should consider the club venue itself. Most strip clubs in 
Portland are small with one or two stages (the more recent clubs are typically larger) but many of the clubs in Las Vegas are of the larger "gentlemen's club" variety, which have a larger capacity and stage formatting. While there is no data at present to answer this it begs the question does a strip-club-per-capita measure really mean anything without a real understanding of what is being measured?

Although the per capita factoid is still widely referenced - even by New York Times columnist Timothy Egan (2008) who suggests that Portland's championing of recycling, bicycling, and urban planning tie in perfectly with the interwoven sex-culture many Portland residents (based on anecdotal reporting) when questioned on the subject of local strip clubs' abundance express ambivalence and in some cases reject any celebratory notions of their presence. For those communities vulnerable to the permeating image of Portland's identity, the struggle to define themselves in contrast to Portland will continue in the form of legislative bills but also through a general anti-Portland attitude. 


\section{Conclusion}

Myths contribute greatly to the ways people identify with place. Myth is many times created through facts or parts of facts. Portland's ranking as a sex-industry hub and "strip club capital" is driven by hyperbole and measures established mostly within the sex industry, as no credible private or government agency maintains any official records of strip clubs in any state (City Club of Portland, 2000). These myths, however serve to recognize part of a unique identity in Portland both in contrast to Oregon and the nation.

Strip clubs and exotic/nude dancing is a subject of growing interest among academic research (Wahab and Baker, 2010). Research suggests that strip clubs are distinct from other adult entertainment and less connected to prostitution than once believed (Frank, 2002; Mestemcher and Roberti, 2004; Lewis, 2006; Bradley-Engen and Ulmer, 2009). Strip clubs still inspire strong community reactions and are not a uniformly accepted fixture in the Portland scenery; however, attitudes about their presence do not provoke the electorate to change the constitutional wording that accelerated their prevalence. Throughout the 1990s and into the 2000s communities around Portland and the rest of Oregon fought against the opening of strip clubs in spite of it being overwhelmingly futile. The repetition of these events from one community to another over time reaches into suburban areas more reflecting NIMBY (not in my backyard) attitudes in a process of spatialization (Shields, 1992). Analysis of voter data from two of the three ballot Measures to amend the constitution suggest that while the statewide margins between those who favor addressing adult entertainment's speech protections narrowed while the margin within the Portland regions widened. 
While the growth of strip clubs in the Portland area has recently ticked upward, the overall growth (even including other adult entertainment) has remained steady since the early 1990s; however, the promotion of the strip club identity as pervasive continues to make commonplace the presence of exotic dancing in Portland's cultural tapestry. Portland's adult industry may not be as large as speculated but contests over these facts perpetuate the place-myth phenomenon. The attachment to the constitutional free speech clause expresses a desire for a cultural imperative above that of the U.S. The concentration of these attitudes in the Portland area further expresses a transgressive identity against that of the national norms (Cresswell, 1996; Carlin, 2010). 


\section{Bibliography}

Allen, Robert C. 1991. Horrible Prettiness: Burlesque and American Culture. Chapel Hill: The University of North Carolina Press.

Agustin, Laura Maria. 2005. "New Research Directions: The Cultural Study of Commercial Sex", Sexualities. 8(5): 618-631.

Bachelard, Gaston. 1964. The Poetics of Space. Beacon Press: Boston.

Barton, Bernadette. 2002. "Dancing on the Möbius Strip: Challenging the Sex War Paradigm", Gender and Society, 16(5): 585-602.

Barton, Bernadette. 2007. "Managing the Toll of Stripping: Boundary Setting among Exotic Dancers", Gender and Society, 36(5): 571-596.

Bates, Tom. (1995, March 20). "Bills Aim to Keep Nudity to Bare Minimum”, The Oregonian, p. B01.

Bella, Rick. (1989, January 9). "Nude Dancing Businesses Proliferate in Portland Area", The Oregonian, p. B01.

Bodine, Harry. (1996, June 17). "Sex \& Sin in Washington County", The Oregonian. p.B02.

Blackmun, Maya. (1990, June 11). "Opponents of Nude Dancing Circulate Petition for Initiative”, The Oregonian, p. D05.

Boule, Margie. (2001, March 18). "Girls Strip Away Their Innocence as Men Sit and Drink", The Oregonian, p.B01.

Bradley-Engen, Mindy and Ulmer, Jeffery T. 2009. "Social Worlds of Stripping: The Processual Orders of Exotic Dance”, The Sociology Quarterly. 50: 26-60.

Brenner, Keri. (1993, September 23). “City Council Supports Pulling Pub’s License”, The Oregonian, p. E02.

Bruckert, C. 2002. Taking It Off, Putting It On: Women in the Sex Trade. Toronto: Women's Press.

Budnick, Nick. (2004, July 7). "Sleeping with the Enemy: Portland's smut wars make strange bedfellows", Willamette Week. Internet: http://www.wweek.com/portland/editorial/3036/5278 
Busse, Phil. (2003, January 23). "Sex Mag Shake-Up! Portland Stripper Magazines Fight For Survival", Internet: http://www.portlandmercury.com/portland/Content?oid=28321\&category $=3$ $\underline{4029}$.

Butler, Judith. 1993. Bodies That Matter: on the Discursive Limits of Sex. Routledge: New York.

Cameron, Samuel. 2004. "Space, Risk and Opportunity: The Evolution of Paid Sex Markets”, Urban Studies, 41(9): 1643-1657.

Carlin, Peter Ames. (2010, April 11). "Sex and the City of Roses", The Oregonian. p.1

City of Nyssa v. Dufloth/Smith, 339 Ore. 330, 121 P.3d 639 (2005)

City Club of Portland Bulletin. (2000 September 22). City Club Research Study: Ballot Measure 87-Zoning of Sexually-Oriented Businesses. 82: 19.

City of Portland v. Derrington, 451 P.2d 111 (1969).

City of Portland v. Tidyman, 759 P.2d 242 (1988).

Clampet, Jennifer. (2008, December 4). "Fighting Off Strip Clubs", Portland Tribune.

Cresswell, Tim. 2005. "Moral Geographies". Cultural geography: a critical dictionary of key concepts. pp. 128-134. Ed. David Atkinson et al. I.B Taurus \& Co Ltd.

- 1996. In Place/Out of Place: Geography, Ideology and Transgression. University of Minnesota Press: Minneapolis.

Coleman, Patrick A. 2009, “The Mercury Booze Issue Presents...Boozing Through the Ages", The Portland Mercury. January 21.

Croy, Dan. (2009, Feb 11). Personal Interview with OLCC License Administrator.

Danta, Darrick. 2009. "Ambiguous landscapes of the San Pornando Valley", Association of Pacific Coast Geographers Yearbook. 71: 15-30.

Davis, Matt. Dec. 20, 2006. "Strip Clubs: Help!” The Portland Mercury. Internet: http://blogtown.portlandmercury.com/2006/12/strip_clubs_help.php

DiStefano, Anne Marie. Nov. 2, 2006. "Fourty Years off Playing Dress-up Looks Good on Darcelle", Portland Tribune. Internet:

http://portlandtribune.com/features/story.php?story_id=116251832755470500 
Diamatteo, Leah. (2010, March 17). "Tracy Doss: Owner of New Laurelhurst Strip Club Talks Neighbors, Bears, and of Course, Strippers", Willamette Week. Internet: http://wweek.com/portland/article-11759-tracy_doss.html

Drake, Monica. (200, September 28). "Support Your Local Sex Worker; An Interview with Teresa Dulce, CO-Organizer of Sex by Sex Workers Film Festival". Portland Mercury, p.7)

Duin, Steve. (1993, April 8). "Strip Joints Have Friends in High Places”, The Oregonian, p.D07.

Edensor, Tim. 2002. National Identity, Popular Culture, and Everyday Life. Berg: Oxford.

Egan, R. Danielle 2003. 'I'll be Your Fantasy Girl, If You'll be My Money Man. Mapping Desire, Fantasy and Power in Two Exotic Dance Clubs", JPCS: The Journal for Psychoanalysis of Culture \& Society, 8: 109-120.

- 2005. "Emotional Consumption: Mapping Love and Masochism in an Exotic Dance Club." Body and Society, 11(4): 87-108.

- 2006. Dancing for Dollars and Paying for Love: The Relationship Between Exotic Dancers and Their Regulars. Pelgrave MacMillan: New York.

Egan, R. Danielle and Frank, Katherine. 2005. "Attempts at a Feminist and Interdisciplinary Conversation about Strip Clubs", Deviant Behavior, 26: 297320.

Egan, R. Danielle; Frank, Katherine; and Johnson, Merri Lisa. 2006. Flesh for Fantasy: Producing and Consuming Exotic Dance. Thunder's Mouth Press: New York.

Egan, Timothy. (2008, August 6). "Nanny Nation", The New York Times, Internet: http://opinionator.blogs.nytimes.com/2008/08/06/nanny-nation

Erickson, David John, and Tewksbury, Richard (2000) 'The 'Gentlemen' in the Club: a Typology of Strip Club Patrons”, Deviant Behavior 21: 271-93.

Frank, Katherine. 2007. "Thinking Critically about Strip Club Research”, Sexualities, 10(4): 501-517.

- 2005. "Exploring the Motivations and Fantasies of Strip Club Customers in Relation to Legal Regulations", Archives of Sexual Behavior, 34: 487-504. 
- 2002. G-Strings and Sympathy: Strip Club Regulars and Male Desire. Durham, N.C.: Duke University Press.

Foden-Vencil, Kristian. (1995, May 12). "March Seeks to Stop Violence against Women", The Oregonian, p. B02.

Foley, Brenda. 2002. "Naked politics: Erie, PA v the Kandyland Club", NWSA Journal. 14(2): 2-17.

Green, Ashbel S. (2005, September 30). "Oregon Justices Defeat Attempts to Limit Sex Shows", The Oregonian, p.A01.

- (1993, September 5). "Portland, Where You Can Get a Good Massage", The Oregonian, p.C04.

Hanna, Judith Lynne. 2003. "Exotic Dance Adult Entertainment: Ethnography Challenges False Mythology”, City \& Society, 15(2): 165-193.

- 2010. "Dance and Sexuality", Journal of Sex Research, 47(2-3), 212-241.

- 2005. "Exotic Dance Adult Entertainment: A Guide for Planners and Policy Makers", Journal of Planning Literature, 20(2): 116-134.

Har, Janie. (2002, August 16). "Panel Puts Limits on Underage Bar Workers", The Oregonian. p. A01

Harvey, David. 1990. The Condition of Postmodernity: and Enquiry into the Origins of Cultural Change. Blackwell Publishing Ltd.: Malden, MA.

- 1996. Justice, nature and the geography of difference. Blackwell Publishing Ltd: Malden, MA.

Hensley, Christopher and Tewksbury, Richard. 2003. Sexual Deviance: A Reader. Lynne Rienner Publishers, Inc: Boulder.

Hogan, Lillian. (2008, February 6). "Boobs with a Side of Soy: Portland Claims World's First Vegan Strip Club", Willamette Week. Internet: http://www.wweek.com/portland/article-8397-boobs_with_a_side_of_soy.html

Hubbard, Phil. 2009. “Opposing Striptopia: The Embattled Spaces of Adult Entertainment”, Sexualities. 12(6): 721-745.

In Re Giannini, 69 Cal. 2d 563 (1968). 
Jarrett, Lucinda. 1997. Stripping in Time: A History of Erotic Dancing. HarperCollins: San Francisco.

Kipnis, Laura. 2006. The Female Thing: Dirt, Envy, Sex, Vulnerability. Vintage Books: New York.

Law, Lisa.1997. "Dancing on the Bar: Sex, Money and the Uneasy Politics of Third Space” pp.107-123. Geographies of Resistance. Ed. Stephen Pile and Michael Keith.

Law, Steve. (2008, January 15). "Mannix Drops Strip-Club Regulation Initiative”, Portland Tribune.

- (2009, June 19). "Lents Says Goodbye to Blight" Portland Tribune.

Las Vegas, Viva. 2009. Magic Gardens (The Memoirs of Viva Las Vegas). Dame Rocket Press: Portland.

Lewis, Jacqueline. 2006. “' I'll Scratch Your Back if You'll Scratch Mine': The Role of Reciprocity, Power and Autonomy in the Strip Club", Canadian Review of Sociology and Anthropology. 43(3): 297-311.

MacKenzie, Bill. (1995, April 13). 'Beaverton 'Gentlemen's Club' Aims to Waltz into Portland", The Oregonian, p.C02.

Marthens, Susan. Moving to Portland. Internet: Accessed 11-18-2009: http://www.movingtoportland.net/.

Mapes, Jeff. (1989, February 1). "Legislators Attack Nude Dancing Issue”, The Oregonian, p. D08.

Mary’s Club. Official Website. http://www.marysclub.com/history.php Accessed 10-312009.

Massey, Doreen. 1994. Space, Place and Gender. University of Minnesota Press: Minneapolis.

—. 2005. For Space. Sage Publications Ltd: London.

Maticka-Tyndale, Eleanor; Lewis, Jacqueline; and Street, Megan. 2005. "Making a Place for Escort Work: A Case Study”, The Journal of Sex Research, 42: 46-53. 
Mestemacher, Rebecca A. and Roberti, Jonathan W. 2004. "Qualitative Analysis of Vocational Choice: a Collective Case Study of Strippers", Deviant Behavior, 25: 43-65.

Mirk, Sarah. (2009, February 11). "Beaver State Loses Top Strip Club Bragging Rights”, Internet:

http://blogtown.portlandmercury.com/BlogtownPDX/archives/2009/02/11/beaver state_loses_top_strip_c.

Moore, Adam S. 2005, March 9. "1995: Bump and Grind”, Willamette Week, internet: www.wweek.com/editorial/3118/6093.

Murphy, Alexandra G. 2003. "The Dialectical Gaze: Exploring the Subject-Object Tension in the Performances of Women who Strip" Journal of Contemporary Ethnography. 32(3): 305-335.

New York Times. Feb 25, 1937; "Minskys See Peril to American 'Art'”, p.10.

Office of Administrative Hearings-Decisions: OLCC (a).The Bank Division Branch Inc FO 94. Internet: Accessed May16th, 2008: http://oah.state.or.us/decisions/Liquor_Control_Commission/.

Office of Administrative Hearings-Decisions: OLCC (b).The Bank Division Branch Inc FO 96. Internet: Accessed May16th, 2008: http://oah.state.or.us/decisions/Liquor_Control_Commission/.

O’Hagan, Maureen. (1999, February 3). “It’s Free Speech, Stupid”, Willamette Week. p.7-10.

Oregonian, (1990, June 1). "48 Hours Show to Mull Area Rift Over Nude Club", p.D2.

Oregonian, (1990, June 5). “OLCC Temporarily Sets Aside Two-Foot Rule”, p.C1.

Oregonian, (1995, June 3). “Neighbors Protest Nude Bar's Expansion”, p. D1.

Oregonian, (2000, October 23). "Endorsements”, Editorial. p.D12.

Oregonian, (2011, January 15). "Shedding the 'Pornland' label", http://www.oregonlive.com/opinion/index.ssf/2011/01/shedding the_pornland_la bel.html 
Park, Robert E. and Burgess, Ernest W. 1925. The City. The University of Chicago Press: Chicago.

Roth v. United States. 354 U.S. 476 (1957).

Rubenstein, Sura. (1991, June22). “In Oregon, Groups Debate Decision's Potential Effects" The Oregonian, p. A01.

Ryder, Andrew. 2004. "The Changing Nature of Adult Entertainment Districts: Between a Rock and a Hard Place or Going from Strength to Strength?" Urban Studies, 41: 1659-1686.

Schiff, Frederick. 1999. "Nude Dancing: Scenes of Sexual Celebration in a Contested Culture" Journal of American Culture. 22(4) 9-16.

Schmidt, Brad. (2009, April 23). "Strip Club Foes Seek Amendment" The Oregonian, p.C01

Schlosser, Eric. 2003. Reefer madness: sex, drugs, and cheap labor in the American black market. Houghton Mifflin Co: New York.

Schulberg, Pete. (1993, November 19). "Mark and Brian Do Portland" The Oregonian, p.E01.

Schweitzer, Dahlia. 2001. "Striptease: The Art of Spectacle and Transgression.” Journal of Popular Culture. 65-75.

Oregon Secretary of State. (1996, November 5). Voters' Pamphlet; State of Oregon General Election.

Oregon Secretary of State. (2000, November 7). Voters' Pamphlet; State of Oregon. Vote by Mail General Election.

Sekne v. City of Portland, 726 P.2d 959 (1986)

Shields, Robert. 1992. Places on the Margin: Alternative Geographies of Modernity. Routledge: London.

Skinner, Marjorie. (2007, June 14). 'Employee of the Week, "Isis Leeor: Counselor and Instructor Becoming Juicy", The Portland Mercury, Internet:

http://www.portlandmercury.com/portland/Content?oid=344576\&category=3989

Smith, David M. 2000. Moral Geographies. Edinburgh University Press. 
Snell, John. (1993, April 24). "Former Boyfriend Kills Co-Owner of Topless Bar" The Oregonian, p.A01

Stanford, Phil. 2004. Portland Confidential: Sex, Crime and Corruption in the Rose City. Graphic Arts Center, Indiana University.

State of Oregon v. Ciancanelli, 339 Ore. 282, 311, 121 P.3d 613 (2005)

State of Oregon v. Henry, 732 P 2d 9 (1987)

State of Oregon v. Brooks, 550 P.2d 440 (1976)

Strip Club Database. Internet: Accessed on 06-11-2008: http://www.stripclubdatabase.com/

Strip Club Map.com. Internet: Accessed on 12-10-2009; http://stripclubmap.com/

Symanski, Richard. 1981. The Immoral Landscape: Female Prostitution in Western Societies. Butterworths: Toronto.

Sweet, N., and Richard Tewksbury. 2000. "Entry, maintenance, and departure from a career in the sex industry: Strippers' experiences of occupational costs and rewards." Humanity and Society 24 (2): 136-61.

The Ultimate Strip Club List. Internet: Accessed on 10-11-2010: http://www.tuscl.net/r.php?RID=7

Trautner, M.N. 2005. "Doing gender, doing class: The performance of sexuality in exotic Dance clubs. Gender \& Society, 19(6): 771-78.

Tuan, Yi-Fu. 1977. Space and Place: The Perspcective of Experience. University of Minnesota Press: Minneapolis.

Uebel, Michael. 2004. “Striptopia?” Social Semiotics, 14:3-19.

Urish, Ben. 2004. "Narrative Striptease in the Nightclub Era." The Journal of American Culture, 27: 157-165.

U.S. Census Bureau. (2010, December 31). Guide to State and Local Census Geography. Internet: Accessed on 10-11-2010: http://www.census.gov/geo/www/guidestloc/guide_main.html

Wahab, Stephanie and Baker, Lynda M. 2010. "Exotic Dance Research: A Review of the Literature from 1970 to 2008 " Sexuality \& Culture. Springer Online. 
West, Darrell M. and Orr, Marion. 2007. "Morality and Economics: Public Assessments of the Adult Entertainment Industry" Economic Development Quarterly. 21(4): 315-324.

Whitehead, Kally and Kurz, Tim. 2009. “Empowerment' and the Pole: A Discursive Investigation of the Reinvention of Pole Dancing as a Recreational Activity" Feminism \& Psychology. 19(2): 224-244.

Zimmerman, Rachel. 1993, April 22. "Look but Don't Touch". Willamette Week. p. 18 
Appendix A

Tables 
Table 1. State Wide Ballot Measures on Free Speech/Obscenity

\begin{tabular}{|lcccccc|}
\hline Measure/Year & Yes & Percent & No & Percent & Total Votes & Margin \\
\hline MSR 19 (1994) & 549,754 & $45.7 \%$ & 652,139 & $54.3 \%$ & $1,201,893$ & $8.52 \%$ \\
\hline MSR 31 (1996) & 630980 & $47.2 \%$ & 706974 & $52.8 \%$ & $1,337,954$ & $5.68 \%$ \\
\hline MSR 87 (2000) & 694,410 & $47.4 \%$ & 771,901 & $52.6 \%$ & $1,466,311$ & $5.28 \%$ \\
\hline
\end{tabular}

Compares statewide ballot Measure results with margins of difference. A yes votes supports changing constitutional language in favor obscenity/adult entertainment zoning regulation.

Source: Oregon Secretary of State, 2010.

Table 2. Yes/No votes of Tri-County Portland Metro region 1996 and 2000

\begin{tabular}{|c|c|c|c|c|c|}
\hline \multicolumn{3}{|c|}{$\begin{array}{c}\text { MSR } 31 \\
1996\end{array}$} & \multicolumn{3}{|c|}{$\begin{array}{c}\text { MSR 87 } \\
2000\end{array}$} \\
\hline $\begin{array}{c}\text { State Rank in } \\
\text { Yes Votes }\end{array}$ & County & $\begin{array}{c}\text { Yes/No } \\
\text { Ratio }\end{array}$ & $\begin{array}{c}\text { State Rank in } \\
\text { Yes Votes }\end{array}$ & County & $\begin{array}{c}\text { Yes/No } \\
\text { Ratio }\end{array}$ \\
\hline 2 & Clackamas & 1.18 & 7 & Clackamas & 1.07 \\
\hline 3 & Washington & 1.12 & 11 & Washington & 1.04 \\
\hline 32 & Multnomah & 0.74 & 33 & Multnomah & 0.71 \\
\hline 1 & Wheeler & 1.22 & 1 & Malhuer & 1.44 \\
\hline \multirow[t]{2}{*}{36} & Harney & 0.55 & 36 & Benton & 0.63 \\
\hline & Range & 0.67 & & Range & 0.82 \\
\hline \multicolumn{6}{|c|}{$\begin{array}{l}\text { Yes votes indicate support for changing constitutional language in favor of } \\
\text { obscenity/adult entertainment zoning regulation. Oregon has } 36 \text { Counties. } \\
\text { Source: Oregon Secretary of State, } 2010 \text {. }\end{array}$} \\
\hline
\end{tabular}


Table 3. Master List for Strip Clubs in the Portland Metropolitan Region 1963-2010

\begin{tabular}{|c|c|c|c|c|c|c|c|}
\hline NAME & City & Stages & Open & Start Date & End Date & $\begin{array}{c}\text { Number of Days } \\
\text { in Operation } \\
\text { through } 2010 \\
\end{array}$ & $\begin{array}{c}\text { Other Club } \\
\text { Location Names }\end{array}$ \\
\hline Mary's Club & Portland & 1 & Yes & $3 / 1 / 1965$ & - & 17220 & \\
\hline The Carriage Room & Portland & 1 & No & $1 / 1 / 1970$ & $12 / 31 / 1988$ & 6840 & \\
\hline Magic Gardens & Portland & 1 & Yes & $10 / 24 / 1975$ & - & 12667 & \\
\hline Pink Pearl Lounge & Portland & 1 & No & $12 / 16 / 1975$ & $12 / 31 / 1988$ & 4695 & \\
\hline Sassy's Bar \& Grill & Portland & 2 & Yes & $8 / 29 / 1977$ & - & 12002 & \\
\hline Acropolis & Portland & 4 & Yes & $10 / 18 / 1977$ & - & 11953 & \\
\hline Club 205 & Portland & 2 & Yes & $7 / 10 / 1981$ & - & 10611 & \\
\hline The Bank, Division Branch & Portland & 1 & No & 3/23/1983 & 7/11/1997 & 5148 & Dancers \\
\hline JD'S Bar 'N' Grill & Portland & 2 & Yes & $1 / 1 / 1984$ & - & 9720 & \\
\hline Tommy's & Portland & 2 & Yes & 2/10/1984 & - & 9681 & Harpo's \\
\hline Pop-A-Top Pub & Portland & 1 & Yes & $7 / 12 / 1984$ & - & 9529 & \\
\hline The Viewpoint & Portland & 3 & Yes & 9/16/1984 & - & 9465 & \\
\hline QT & Sherwood & 1 & No & $1 / 1 / 1985$ & $9 / 1 / 1996$ & 4200 & \\
\hline Pirate's Cove & Portland & 2 & Yes & $1 / 8 / 1985$ & - & 9353 & Sandy Jug \\
\hline Jody'S Bar \& Grill & Portland & 3 & Yes & $8 / 15 / 1985$ & - & 9136 & \\
\hline Cabaret II & Gresham & 3 & Yes & $8 / 20 / 1985$ & - & 9131 & CJ'S /City Limits \\
\hline Cy's Parkrose Pub & Portland & 1 & No & $12 / 18 / 1985$ & $2 / 11 / 1995$ & 3293 & Graphic Tavern \\
\hline JBs Paradise Room & Portland & 1 & No & $1 / 1 / 1986$ & $1 / 1 / 1989$ & 1080 & \\
\hline Boring Tavern & Boring & 1 & Yes & $3 / 6 / 1986$ & - & 8935 & \\
\hline The Tin Quill & Portland & 1 & No & $1 / 1 / 1987$ & $11 / 30 / 1991$ & 1769 & \\
\hline Loading Zone Inc. & Portland & 1 & No & $1 / 21 / 1987$ & $3 / 16 / 1990$ & 1135 & \\
\hline Jiggles & Tualatin & 2 & Yes & $5 / 18 / 1987$ & - & 8503 & \\
\hline The Squirel Cage & Wilsonville & 1 & No & $10 / 1 / 1987$ & $1 / 1 / 1998$ & 3690 & \\
\hline Pink Pearl East & Portland & 1 & No & $11 / 3 / 1987$ & 2/10/1990 & 817 & \\
\hline The Dolphin III & Oak Grove & 4 & Yes & $11 / 17 / 1987$ & - & 8324 & Dillinger's \\
\hline
\end{tabular}


Table 3. Master List for Strip Clubs in the Portland Metropolitan Region 1963-2010

\begin{tabular}{|c|c|c|c|c|c|c|c|}
\hline NAME & City & Stages & Open & Start Date & End Date & $\begin{array}{l}\text { Number of Days } \\
\text { in Operation } \\
\text { through } 2010\end{array}$ & $\begin{array}{c}\text { Other Club } \\
\text { Location Names }\end{array}$ \\
\hline Coconuts & Hillsboro & 1 & No & $5 / 18 / 1988$ & $7 / 14 / 1990$ & 776 & \\
\hline Satin Doll & Portland & 2 & No & $1 / 25 / 1989$ & $3 / 19 / 1998$ & 3294 & \\
\hline Backswing & Portland & 1 & No & $11 / 23 / 1989$ & $6 / 22 / 2006$ & 5969 & Top Hats and Tails \\
\hline Dancin' Bare & Portland & 3 & Yes & 12/14/1989 & - & 7577 & \\
\hline Beavers & Portland & 1 & No & $2 / 28 / 1990$ & $1 / 1 / 1996$ & 2101 & \\
\hline Union Jacks & Portland & 1 & Yes & $3 / 27 / 1990$ & - & 7474 & \\
\hline The Dolphin I & Milwaukie & 3 & Yes & 7/9/1990 & - & 7372 & \\
\hline R\&M Club & Portland & 1 & No & $10 / 11 / 1990$ & 2/11/1997 & 2280 & Night Owl \\
\hline EJ'S Bar & Portland & 1 & No & $1 / 1 / 1991$ & $12 / 31 / 1994$ & 7200 & \\
\hline Calico Cat & Portland & 2 & No & $6 / 15 / 1991$ & $11 / 23 / 2002$ & 4118 & \\
\hline Double Dribble Tavern & Portland & 4 & Yes & 7/18/1991 & - & 7003 & Sugar Daddys \\
\hline 92Nd Street Club & Portland & 3 & No & $8 / 21 / 1991$ & $12 / 31 / 2008$ & 6970 & \\
\hline Tommy's III & Portland & 2 & Yes & 12/11/1991 & - & 6860 & Soapy's \\
\hline Safari Showclub & Portland & 3 & Yes & $3 / 17 / 1992$ & - & 6764 & Doc's Bar \& Grill \\
\hline Webb's Pub & Portland & 1 & No & $5 / 26 / 1992$ & $12 / 31 / 2000$ & 3095 & \\
\hline Bottoms Up! & St Helens & 1 & Yes & $6 / 15 / 1992$ & - & 6676 & \\
\hline Blush & Portland & 2 & Yes & 8/4/1992 & - & 6627 & Club Cabos /Hatties \\
\hline The Pallas & Portland & 3 & Yes & 9/16/1992 & - & 6585 & Club Genesis \\
\hline Kasbah & Portland & 2 & No & $1 / 1 / 1993$ & $12 / 31 / 1996$ & 1440 & Wild Orchid /Chi Chi's \\
\hline Riverside Corral & Portland & 3 & Yes & 7/20/1993 & - & 6281 & \\
\hline 505 Club & Gresham & 3 & Yes & $8 / 12 / 1993$ & - & 6259 & \\
\hline Dooley'S Lounge & Portland & 1 & No & $5 / 10 / 1994$ & $12 / 31 / 1998$ & 2391 & \\
\hline Club 122 & Portland & 2 & No & $5 / 26 / 1994$ & 7/17/1997 & 1131 & \\
\hline Dooley's Of St. Johns & Portland & 1 & No & $12 / 1 / 1994$ & $12 / 31 / 2005$ & 5790 & Shagnasty's \\
\hline Club Paradise & Portland & 2 & No & $12 / 13 / 1994$ & 2/9/1996 & 416 & \\
\hline
\end{tabular}


Table 3. Master List for Strip Clubs in the Portland Metropolitan Region 1963-2010

\begin{tabular}{|c|c|c|c|c|c|c|c|}
\hline NAME & City & Stages & Open & Start Date & End Date & $\begin{array}{c}\text { Number of Days } \\
\text { in Operation } \\
\text { through } 2010\end{array}$ & $\begin{array}{c}\text { Other Club } \\
\text { Location Names }\end{array}$ \\
\hline Montego's & Portland & 2 & Yes & $12 / 19 / 1994$ & - & 5772 & \\
\hline Mama Mia's & Beaverton & 2 & No & $5 / 1 / 1995$ & $12 / 31 / 1997$ & 960 & \\
\hline Dream On Saloon & Portland & 2 & Yes & $6 / 13 / 1995$ & - & 5598 & \\
\hline Nicolai St. Clubhouse & Portland & 2 & Yes & $6 / 23 / 1995$ & - & 5588 & Red's Sidetrack \\
\hline Hawthorne Strip & Portland & 1 & Yes & 9/19/1995 & - & 5502 & Dino's Inn \\
\hline Rooster's & Portland & 2 & Yes & $11 / 3 / 1995$ & - & 5458 & \\
\hline Stars Cabaret Beaverton & Beaverton & 2 & Yes & $6 / 12 / 1996$ & - & 5239 & \\
\hline Lucky Devil Lounge & Portland & 1 & Yes & 2/1/1998 & - & 4650 & Club Coco II /Boom Boom Room East \\
\hline Exotica International & Portland & 3 & Yes & 9/20/1999 & - & 4061 & \\
\hline Hotties & Beaverton & 1 & Yes & 9/20/1999 & - & 4061 & Wildcats \\
\hline Club 82 & Portland & 1 & Yes & $12 / 1 / 1999$ & - & 3990 & Hideawy Pub \\
\hline Cocktails And Dreams & Portland & 4 & Yes & $7 / 25 / 2000$ & - & 3756 & \\
\hline Devils Point & Portland & 1 & Yes & $12 / 13 / 2000$ & - & 3618 & Siver Dollar Saloon \\
\hline DV8 & Portland & 2 & Yes & $6 / 8 / 2001$ & - & 3443 & \\
\hline The Dolphin II & Beaverton & 4 & Yes & $12 / 21 / 2001$ & - & 3250 & \\
\hline Boom Boom Room & Portland & 1 & Yes & $10 / 12 / 1998$ & - & 4399 & \\
\hline The Big Bang & Portland & 2 & Yes & $11 / 14 / 2002$ & - & 2927 & \\
\hline Tommy's Too & Portland & 2 & Yes & $6 / 10 / 2004$ & - & 2361 & \\
\hline Cabaret & Portland & 2 & Yes & $6 / 21 / 2004$ & - & 2350 & \\
\hline The Sunset Strip & Beaverton & 2 & Yes & $9 / 9 / 2004$ & - & 2272 & \\
\hline Soobie's & Portland & 4 & Yes & $6 / 13 / 2005$ & - & 1998 & \\
\hline Carnaval & Portland & 2 & Yes & $7 / 21 / 2006$ & - & 1600 & \\
\hline Casa Diablo Gentlemens Club & Portland & 2 & Yes & $8 / 7 / 2007$ & - & 1224 & \\
\hline Spyce Gentlemen'S Club & Portland & 2 & Yes & $9 / 5 / 2008$ & - & 836 & \\
\hline Club Rouge & Portland & 1 & Yes & $10 / 6 / 2008$ & - & 805 & \\
\hline
\end{tabular}


Table 3. Master List for Strip Clubs in the Portland Metropolitan Region 1963-2010

\begin{tabular}{|lcccccc|}
\hline NAME & & & & & & $\begin{array}{c}\text { Number of Days } \\
\text { in Operation } \\
\text { through } 2010\end{array}$ \\
\hline Stars Cabaret Bridgeport & City & Stages & Open & Start Date & End Date & 778 \\
\hline Mystic Gentlemen's Club & Portland & 2 & Yes & $6 / 2 / 2009$ & - & 569 \\
\hline Mynt Gentlemen'sClub & Portland & 2 & Yes & $11 / 17 / 2009$ & - & 404 \\
\hline Heat & Portland & 2 & Yes & $10 / 5 / 2010$ & - & 86 \\
\hline
\end{tabular}

List Ranked by date of opening

Club locations were compiled by references in trade publications (example

Exotica ), OLCC records, and news media. Business names were crossreferenced

with the Secretary of States Business Registry for verificaion where possible. 
Table 4. State Ballot Initiative Measure 31 (year 1996) Election Results by County

\begin{tabular}{|c|c|c|c|c|c|c|}
\hline County & Yes & No & Difference & Total & Margin & Yes/No Ratio \\
\hline Baker & 3,362 & 4,130 & -768 & 7,492 & $-10.25 \%$ & 0.814 \\
\hline Benton & 13,171 & 20,727 & $-7,556$ & 33,898 & $-22.29 \%$ & 0.635 \\
\hline Clackamas & 76,078 & 64,277 & 11,801 & 140,355 & $8.41 \%$ & 1.184 \\
\hline Clatsop & 6,376 & 8,533 & $-2,157$ & 14,909 & $-14.47 \%$ & 0.747 \\
\hline Columbia & 9,294 & 8,756 & 538 & 18,050 & $2.98 \%$ & 1.061 \\
\hline Coos & 11,679 & 15,431 & $-3,752$ & 27,110 & $-13.84 \%$ & 0.757 \\
\hline Crook & 3,257 & 3,599 & -342 & 6,856 & $-4.99 \%$ & 0.905 \\
\hline Curry & 5,417 & 5,120 & 297 & 10,537 & $2.82 \%$ & 1.058 \\
\hline Deschutes & 21,317 & 23,055 & $-1,738$ & 44,372 & $-3.92 \%$ & 0.925 \\
\hline Douglas & 19,838 & 22,172 & $-2,334$ & 42,010 & $-5.56 \%$ & 0.895 \\
\hline Gilliam & 443 & 572 & -129 & 1,015 & $-12.71 \%$ & 0.774 \\
\hline Grant & 1,839 & 1,959 & -120 & 3,798 & $-3.16 \%$ & 0.939 \\
\hline Harney & 1,236 & 2,238 & $-1,002$ & 3,474 & $-28.84 \%$ & 0.552 \\
\hline Hood River & 3,653 & 3,714 & -61 & 7,367 & $-0.83 \%$ & 0.984 \\
\hline Jackson & 31,784 & 39,272 & $-7,488$ & 71,056 & $-10.54 \%$ & 0.809 \\
\hline Jefferson & 3,013 & 3,078 & -65 & 6,091 & $-1.07 \%$ & 0.979 \\
\hline Josephine & 15,022 & 16,527 & $-1,505$ & 31,549 & $-4.77 \%$ & 0.909 \\
\hline Klamath & 11,724 & 12,570 & -846 & 24,294 & $-3.48 \%$ & 0.933 \\
\hline Lake & 1,691 & 1,877 & -186 & 3,568 & $-5.21 \%$ & 0.901 \\
\hline Lane & 53,030 & 80,761 & $-27,731$ & 133,791 & $-20.73 \%$ & 0.657 \\
\hline Lincoln & 9,554 & 10,431 & -877 & 19,985 & $-4.39 \%$ & 0.916 \\
\hline Linn & 19,946 & 19,298 & 648 & 39,244 & $1.65 \%$ & 1.034 \\
\hline Malheur & 5,071 & 4,616 & 455 & 9,687 & $4.70 \%$ & 1.099 \\
\hline Marion & 53,538 & 51,493 & 2,045 & 105,031 & $1.95 \%$ & 1.040 \\
\hline Morrow & 1,566 & 1,679 & -113 & 3,245 & $-3.48 \%$ & 0.933 \\
\hline Multnomah & 111,736 & 150,484 & $-38,748$ & 262,220 & $-14.78 \%$ & 0.743 \\
\hline Polk & 12,665 & 11,917 & 748 & 24,582 & $3.04 \%$ & 1.063 \\
\hline Sherman & 513 & 519 & -6 & 1,032 & $-0.58 \%$ & 0.988 \\
\hline Tillamook & 5,396 & 5,622 & -226 & 11,018 & $-2.05 \%$ & 0.960 \\
\hline Umatilla & 9,547 & 11,077 & $-1,530$ & 20,624 & $-7.42 \%$ & 0.862 \\
\hline Union & 4,613 & 6,702 & $-2,089$ & 11,315 & $-18.46 \%$ & 0.688 \\
\hline Wallowa & 1,859 & 2,322 & -463 & 4,181 & $-11.07 \%$ & 0.801 \\
\hline Wasco & 4,805 & 4,855 & -50 & 9,660 & $-0.52 \%$ & 0.990 \\
\hline Washington & 80,784 & 72,374 & 8,410 & 153,158 & $5.49 \%$ & 1.116 \\
\hline Wheeler & 467 & 383 & 84 & 850 & $9.88 \%$ & 1.219 \\
\hline Yamhill & 15,696 & 14,834 & 862 & 30,530 & $2.82 \%$ & 1.058 \\
\hline Total & 630,980 & 706,974 & $-75,994$ & $1,337,954$ & $-5.68 \%$ & 0.89 \\
\hline
\end{tabular}

Amends Constitution: Obscenity May Receive No Greater Protection Than Under Federal Constitution 
Table 5. State Ballot Initiative Measure 87 (year 2000) Election Results by County

\begin{tabular}{|c|c|c|c|c|c|c|}
\hline County & Yes & No & Difference & Total & Margin & Yes/No Ratio \\
\hline BAKER & 4,056 & 3,946 & 110 & 8,002 & $1.37 \%$ & 1.028 \\
\hline BENTON & 14,262 & 22,755 & $-8,493$ & 37,017 & $-22.94 \%$ & 0.627 \\
\hline CLACKAMAS & 78,787 & 73,563 & 5,224 & 152,350 & $3.43 \%$ & 1.071 \\
\hline CLATSOP & 6,656 & 9,441 & $-2,785$ & 16,097 & $-17.30 \%$ & 0.705 \\
\hline COLUMBIA & 9,869 & 10,761 & -892 & 20,630 & $-4.32 \%$ & 0.917 \\
\hline coos & 13,793 & 14,713 & -920 & 28,506 & $-3.23 \%$ & 0.937 \\
\hline CROOK & 4,094 & 3,940 & 154 & 8,034 & $1.92 \%$ & 1.039 \\
\hline CURRY & 5,252 & 5,703 & -451 & 10,955 & $-4.12 \%$ & 0.921 \\
\hline DESCHUTES & 27,224 & 28,851 & $-1,627$ & 56,075 & $-2.90 \%$ & 0.944 \\
\hline DOUGLAS & 23,249 & 22,829 & 420 & 46,078 & $0.91 \%$ & 1.018 \\
\hline GILLIAM & 469 & 590 & -121 & 1,059 & $-11.43 \%$ & 0.795 \\
\hline GRANT & 1,934 & 1,676 & 258 & 3,610 & $7.15 \%$ & 1.154 \\
\hline HARNEY & 1,755 & 1,811 & -56 & 3,566 & $-1.57 \%$ & 0.969 \\
\hline HOOD RIVER & 3,835 & 4,406 & -571 & 8,241 & $-6.93 \%$ & 0.870 \\
\hline JACKSON & 43,129 & 39,043 & 4,086 & 82,172 & $4.97 \%$ & 1.105 \\
\hline JEFFERSON & 3,266 & 3,437 & -171 & 6,703 & $-2.55 \%$ & 0.950 \\
\hline JOSEPHINE & 17,803 & 17,860 & -57 & 35,663 & $-0.16 \%$ & 0.997 \\
\hline KLAMATH & 13,247 & 13,820 & -573 & 27,067 & $-2.12 \%$ & 0.959 \\
\hline LAKE & 1,866 & 1,730 & 136 & 3,596 & $3.78 \%$ & 1.079 \\
\hline LANE & 58,358 & 84,575 & $-26,217$ & 142,933 & $-18.34 \%$ & 0.690 \\
\hline LINCOLN & 8,842 & 11,647 & $-2,805$ & 20,489 & $-13.69 \%$ & 0.759 \\
\hline LINN & 21,051 & 20,806 & 245 & 41,857 & $0.59 \%$ & 1.012 \\
\hline MALHEUR & 5,983 & 4,144 & 1,839 & 10,127 & $18.16 \%$ & 1.444 \\
\hline MARION & 56,072 & 53,796 & 2,276 & 109,868 & $2.07 \%$ & 1.042 \\
\hline MORROW & 1,634 & 1,878 & -244 & 3,512 & $-6.95 \%$ & 0.870 \\
\hline MULTNOMAH & 117,913 & 165,693 & $-47,780$ & 283,606 & $-16.85 \%$ & 0.712 \\
\hline POLK & 13,861 & 12,942 & 919 & 26,803 & $3.43 \%$ & 1.071 \\
\hline SHERMAN & 509 & 515 & -6 & 1,024 & $-0.59 \%$ & 0.988 \\
\hline TILLAMOOK & 5,449 & 6,568 & $-1,119$ & 12,017 & $-9.31 \%$ & 0.830 \\
\hline UMATILLA & 9,706 & 11,961 & $-2,255$ & 21,667 & $-10.41 \%$ & 0.811 \\
\hline UNION & 5,452 & 6,196 & -744 & 11,648 & $-6.39 \%$ & 0.880 \\
\hline WALLOWA & 2,146 & 1,989 & 157 & 4,135 & $3.80 \%$ & 1.079 \\
\hline WASCO & 5,113 & 5,235 & -122 & 10,348 & $-1.18 \%$ & 0.977 \\
\hline WASHINGTON & 89,347 & 86,155 & 3,192 & 175,502 & $1.82 \%$ & 1.037 \\
\hline WHEELER & 380 & 441 & -61 & 821 & $-7.43 \%$ & 0.862 \\
\hline YAMHILL & 18,048 & 16,485 & 1,563 & 34,533 & $4.53 \%$ & 1.095 \\
\hline TOTAL & 694,410 & 771,901 & $-77,491$ & $1,466,311$ & $-5.28 \%$ & 0.900 \\
\hline
\end{tabular}

Amends Constitution: Allows Regulation of Location of Sexually Oriented Businesses Through Zoning 
Table 6. City Ranks (most populous) for Strip Clubs per Capita using 2008 Populations and Club Lists

\begin{tabular}{rccccc} 
City & $\begin{array}{c}\text { Club } \\
\text { Count }\end{array}$ & $\begin{array}{c}2008 \\
\text { Population }\end{array}$ & $\begin{array}{c}\text { Clubs per } \\
100 \mathrm{~K} \\
\text { Persons }\end{array}$ & $\begin{array}{c}\text { Rank for } 100 \\
\text { Most Populous } \\
\text { Cities }\end{array}$ & $\begin{array}{c}\text { Rank for all } \\
\text { Cities }\end{array}$ \\
\hline Tampa & 24 & 340,108 & 7.06 & 1 & 289 \\
\hline Atlanta & 35 & 537,385 & 6.51 & 2 & 306 \\
\hline Baltimore & 39 & 638,091 & 6.11 & 3 & 316 \\
\hline New Orleans & 20 & 336,644 & 5.94 & 4 & 324 \\
\hline Salt Lake City & 9 & 180,722 & 4.98 & 5 & 363 \\
\hline Las Vegas & 28 & 562,849 & 4.97 & 6 & 364 \\
\hline Miami & 19 & 431,196 & 4.41 & 7 & 392 \\
\hline Fort Lauderdale & 8 & 183,220 & 4.37 & 8 & 395 \\
\hline Portland & 24 & 556,442 & 4.31 & 9 & 397 \\
\hline Norfolk & 10 & 234,653 & 4.26 & 10 & 401
\end{tabular}

Data for the 2008 club list is not considered accurate but reflects the disparity between the many lists available.

Table 7. City Ranks (most populous) for Strip Clubs per Capita using 2010 Populations and Club Lists

\begin{tabular}{rccccc} 
City & $\begin{array}{c}\text { Club } \\
\text { Count }\end{array}$ & $\begin{array}{c}2010 \\
\text { Population }\end{array}$ & $\begin{array}{c}\text { Clubs per } \\
100 \mathrm{~K} \\
\text { Persons }\end{array}$ & $\begin{array}{c}\text { Rank for 100 } \\
\text { Most Populous } \\
\text { Cities }\end{array}$ & $\begin{array}{c}\text { Rank for all } \\
\text { Cities }\end{array}$ \\
\hline Portland & 56 & 583,776 & 9.59 & 1 & 694 \\
\hline Atlanta & 36 & 420,003 & 8.57 & 2 & 609 \\
\hline Akron & 17 & 199,110 & 8.54 & 3 & 696 \\
\hline Tampa & 27 & 335,709 & 8.04 & 4 & 446 \\
\hline Fayetteville, NC & 16 & 200,564 & 7.98 & 5 & 641 \\
\hline New Orleans & 21 & 343,829 & 6.11 & 6 & 711 \\
\hline Miami & 21 & 399,457 & 5.26 & 7 & 610 \\
\hline Baltimore & 31 & 620,961 & 4.99 & 8 & 717 \\
\hline Las Vegas & 28 & 583,756 & 4.80 & 9 & 579 \\
\hline Cleveland & 19 & 396,815 & 4.79 & 10 & 642
\end{tabular}

City geography and population based on U.S. Census Bureau Census Designated Place data. 
Table 8. Urbanized Area Ranks (most populous) for Strip Clubs per Capita using 2010 Populations and Club Lists

\begin{tabular}{rccccc} 
Urbanized Area (UA) & $\begin{array}{c}\text { Club } \\
\text { Count }\end{array}$ & $\begin{array}{c}2010 \\
\text { Population }\end{array}$ & $\begin{array}{c}\text { Clubs per } \\
\text { 100K Persons }\end{array}$ & $\begin{array}{c}\text { Rank for 100 } \\
\text { Most Populous } \\
\text { UAs }\end{array}$ & $\begin{array}{c}\text { Rank for all } \\
\text { UAs }\end{array}$ \\
\hline Akron, OH & 22 & 559,329 & 3.93 & 1 & 9 \\
\hline Portland, OR--WA & 68 & $1,819,793$ & 3.74 & 2 & 10 \\
\hline New Orleans, LA & 26 & 823,957 & 3.16 & 3 & 14 \\
\hline Jacksonville, FL & 23 & 949,349 & 2.42 & 4 & 29 \\
\hline Tampa--St. Petersburg, FL & 53 & $2,231,415$ & 2.38 & 5 & 31 \\
\hline Palm Bay--Melbourne, FL & 10 & 430,957 & 2.32 & 6 & 32 \\
\hline Honolulu, HI & 18 & 784,295 & 2.30 & 7 & 33 \\
\hline Oklahoma City, OK & 18 & 820,245 & 2.19 & 8 & 35 \\
\hline Youngstown, OH--PA & 8 & 372,758 & 2.15 & 9 & 41
\end{tabular}

Urbanized Area geography and population based on U.S. Census Bureau Urban Area data. This does not include Urban Clusters.

Table 9. Metropolitan Statistical Area (most populous) Ranks for Strip Clubs per Capita using 2010 Populations and Club Lists

\begin{tabular}{|c|c|c|c|c|c|}
\hline $\begin{array}{r}\text { Metropolitan Statistical Area } \\
\text { (MSA) }\end{array}$ & $\begin{array}{l}\text { Club } \\
\text { Count }\end{array}$ & $\begin{array}{c}2010 \\
\text { Population }\end{array}$ & $\begin{array}{c}\text { Clubs per } \\
\text { 100K Persons }\end{array}$ & $\begin{array}{l}\text { Rank for } 100 \\
\text { Most Populous } \\
\text { MSAs }\end{array}$ & $\begin{array}{l}\text { Rank } \\
\text { for all } \\
\text { MSAs }\end{array}$ \\
\hline Akron, $\mathrm{OH}$ & 24 & 703,200 & 3.41 & 1 & 7 \\
\hline Portland-Vancouver, OR-WA & 69 & $2,226,009$ & 3.10 & 2 & 11 \\
\hline New Orleans, LA & 27 & $1,167,764$ & 2.31 & 3 & 23 \\
\hline Tampa, FL & 55 & $2,783,243$ & 1.98 & 4 & 29 \\
\hline Youngstown-Warren, OH-PA & 11 & 565,773 & 1.94 & 5 & 31 \\
\hline Honolulu, HI & 18 & 953,207 & 1.89 & 6 & 34 \\
\hline El Paso, TX & 15 & 800,647 & 1.87 & 7 & 35 \\
\hline Palm Bay, FL & 10 & 543,376 & 1.84 & 8 & 39 \\
\hline Jacksonville, FL & 24 & $1,345,596$ & 1.78 & 9 & 45 \\
\hline Greensboro, NC & 12 & 723,801 & 1.66 & 10 & 49 \\
\hline
\end{tabular}

MSA geography and population based on U.S. Census Bureau Metropolitan Statistical Area data. 
Table 10. Urbanized Area Ranks for Strip Clubs per Capita using 2010 Populations and Club Lists

\begin{tabular}{rcccc} 
Urbanized Area (UA) & $\begin{array}{c}\text { Club } \\
\text { Count }\end{array}$ & $\begin{array}{c}2010 \\
\text { Population }\end{array}$ & $\begin{array}{c}\text { Clubs per 100K } \\
\text { Persons }\end{array}$ & $\begin{array}{c}\text { Rank for All } \\
\text { UAs }\end{array}$ \\
\hline Myrtle Beach, SC & 14 & 142,044 & 9.86 & 1 \\
\hline Kokomo, IN & 6 & 62,137 & 9.66 & 2 \\
\hline Atlantic City, NJ & 14 & 234,573 & 5.97 & 3 \\
\hline Jackson, MI & 5 & 86,695 & 5.77 & 4 \\
\hline Fayetteville, NC & 16 & 291,201 & 5.49 & 5 \\
\hline Dothan, AL & 3 & 65,824 & 4.56 & 6 \\
\hline Dover, DE & 3 & 72,589 & 4.13 & 7 \\
\hline Jacksonville, NC & 4 & 99,911 & 4.00 & 8 \\
\hline Akron, OH & 22 & 559,329 & 3.93 & 9
\end{tabular}

Urbanized Area geography and population based on U.S. Census Bureau Urban Area data. This does not include Urban Clusters.

Table 11. *Metropolitan Statistical Area Ranks for Strip Clubs per Capita using 2010 Populations and Club Lists

\begin{tabular}{|c|c|c|c|c|}
\hline $\begin{array}{r}\text { Metropolitan Statistical Area } \\
\text { (MSA) }\end{array}$ & $\begin{array}{l}\text { Club } \\
\text { Count }\end{array}$ & $\begin{array}{c}2010 \\
\text { Population }\end{array}$ & $\begin{array}{c}\text { Clubs per } \\
\text { 100K Persons }\end{array}$ & $\begin{array}{l}\text { Rank for all } \\
\text { MSAs }\end{array}$ \\
\hline Kokomo, IN & 6 & 98,688 & 6.08 & 1 \\
\hline Atlantic City-Hammonton, NJ & 16 & 274,549 & 5.83 & 2 \\
\hline Myrtle Beach-Conway, SC & 15 & 269,291 & 5.57 & 3 \\
\hline Fayetteville, NC & 16 & 366,383 & 4.37 & 4 \\
\hline Fort Wayne, IN & 6 & 416,257 & 3.74 & 5 \\
\hline Lawrence, KS & 4 & 110,826 & 3.61 & 6 \\
\hline Akron, $\mathrm{OH}$ & 24 & 703,200 & 3.41 & 7 \\
\hline Crestview-Fort Walton Beach, FL & 6 & 180,822 & 3.32 & 8 \\
\hline Manhattan, KS & 4 & 127,081 & 3.15 & 9 \\
\hline Huntsville, AL & 13 & 417,593 & 3.11 & 10 \\
\hline
\end{tabular}

MSA geography and population based on U.S. Census Bureau Metropolitan Statistical Area data.

* The Portland Area ranked 12 in this list noted in the 100 most populous MSA table above. 
Appendix B

Figures 
Figure 1. Yes/No vote ratio and strip club distance. Based on distributed voter precinct data. Source: Oregon Secretary of State, Multnomah, Washington, and Clackamas County Elections.

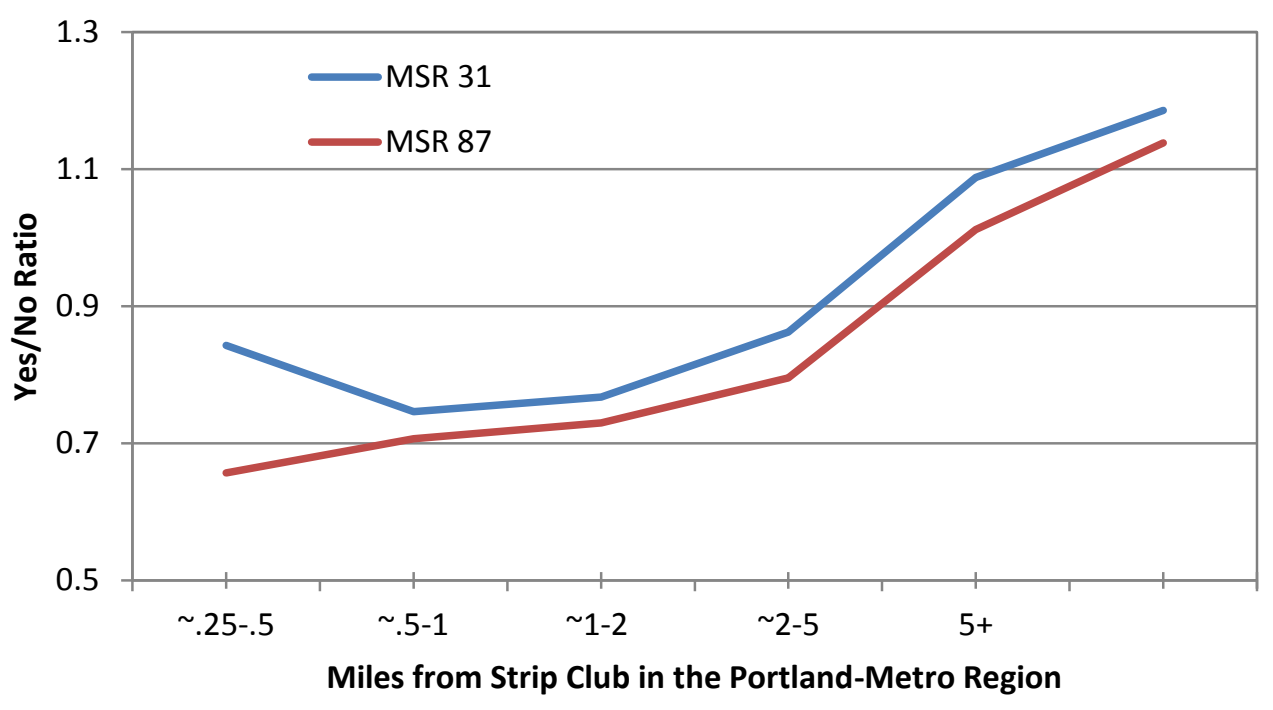




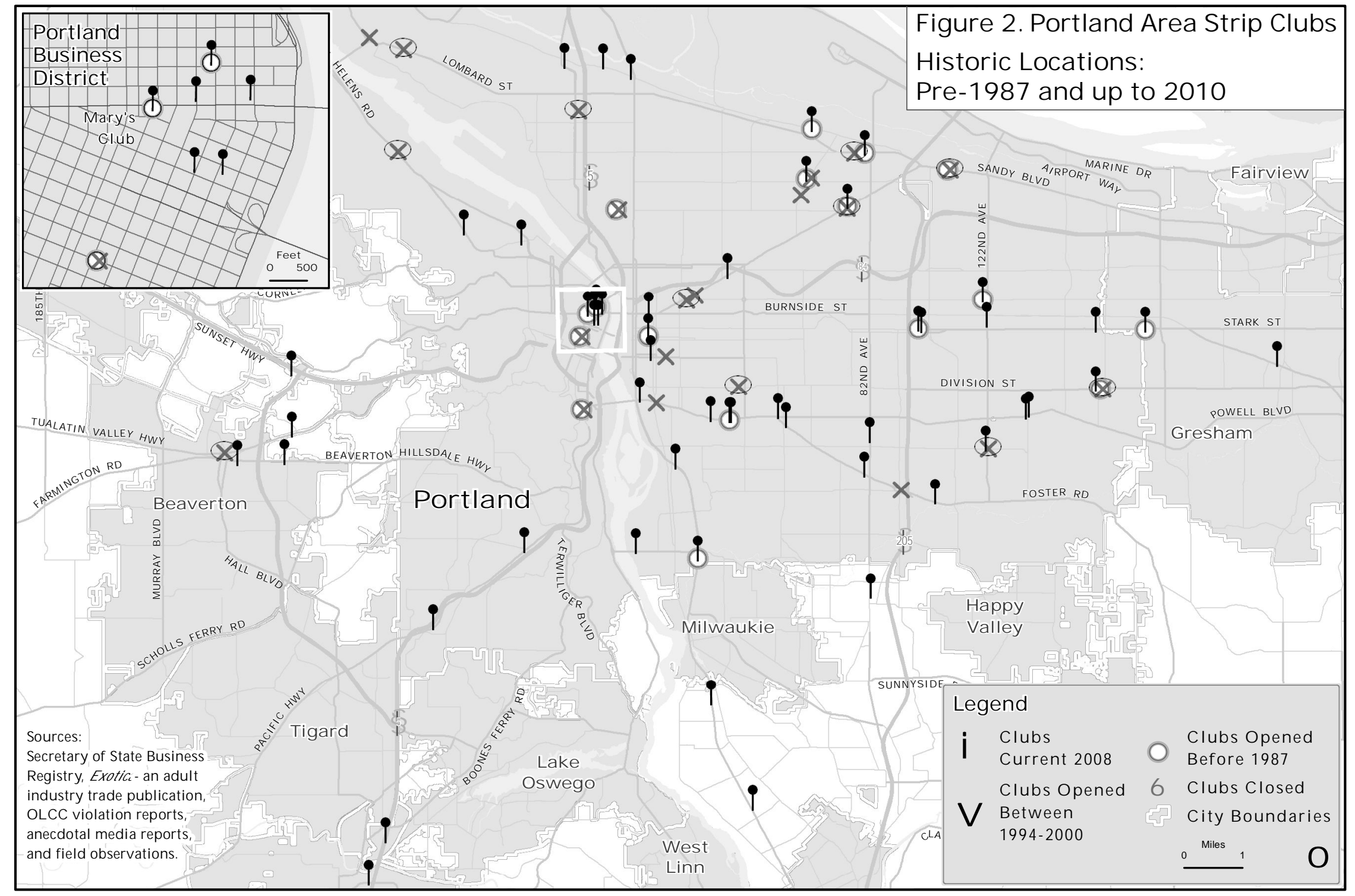




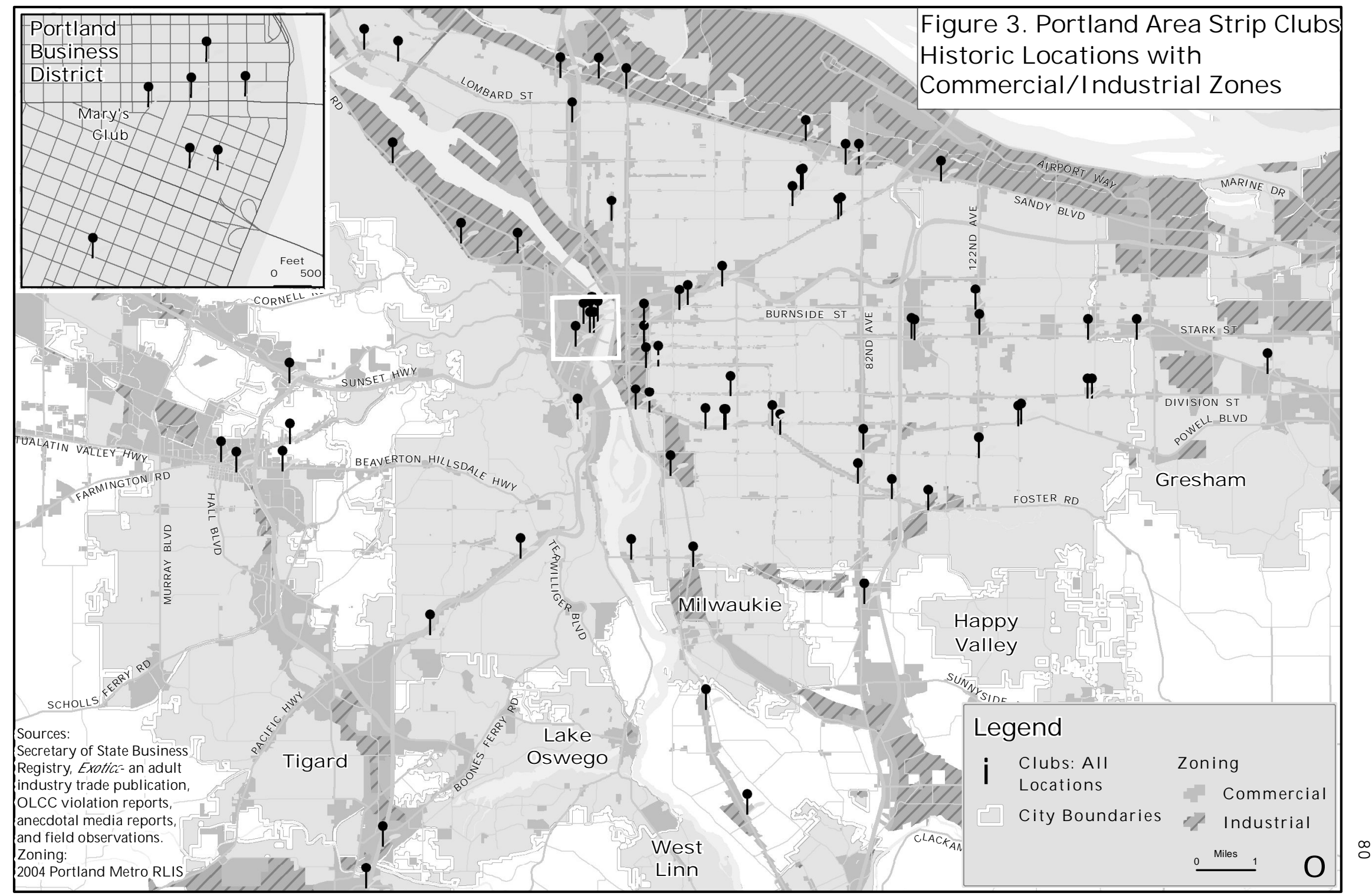




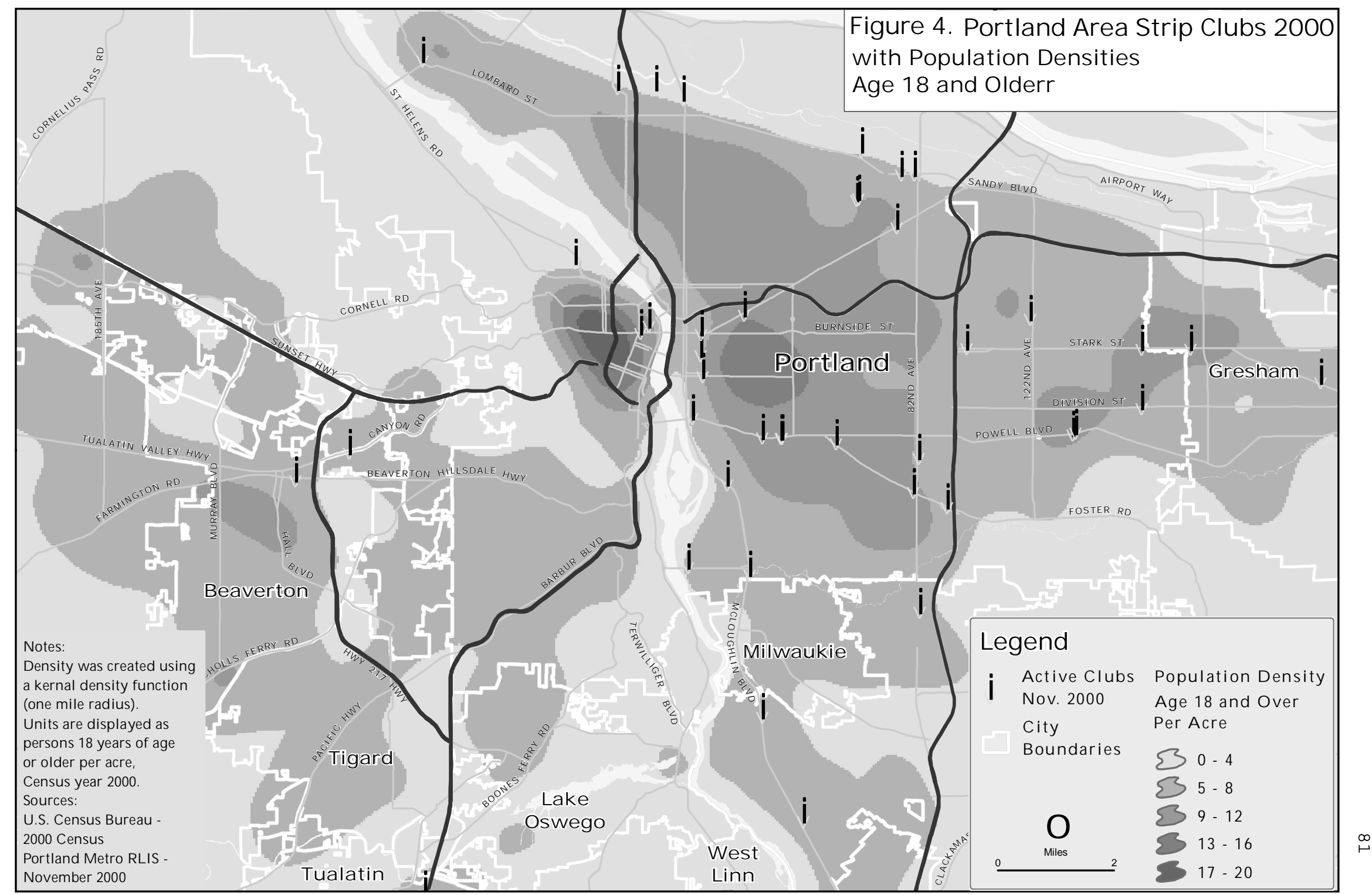




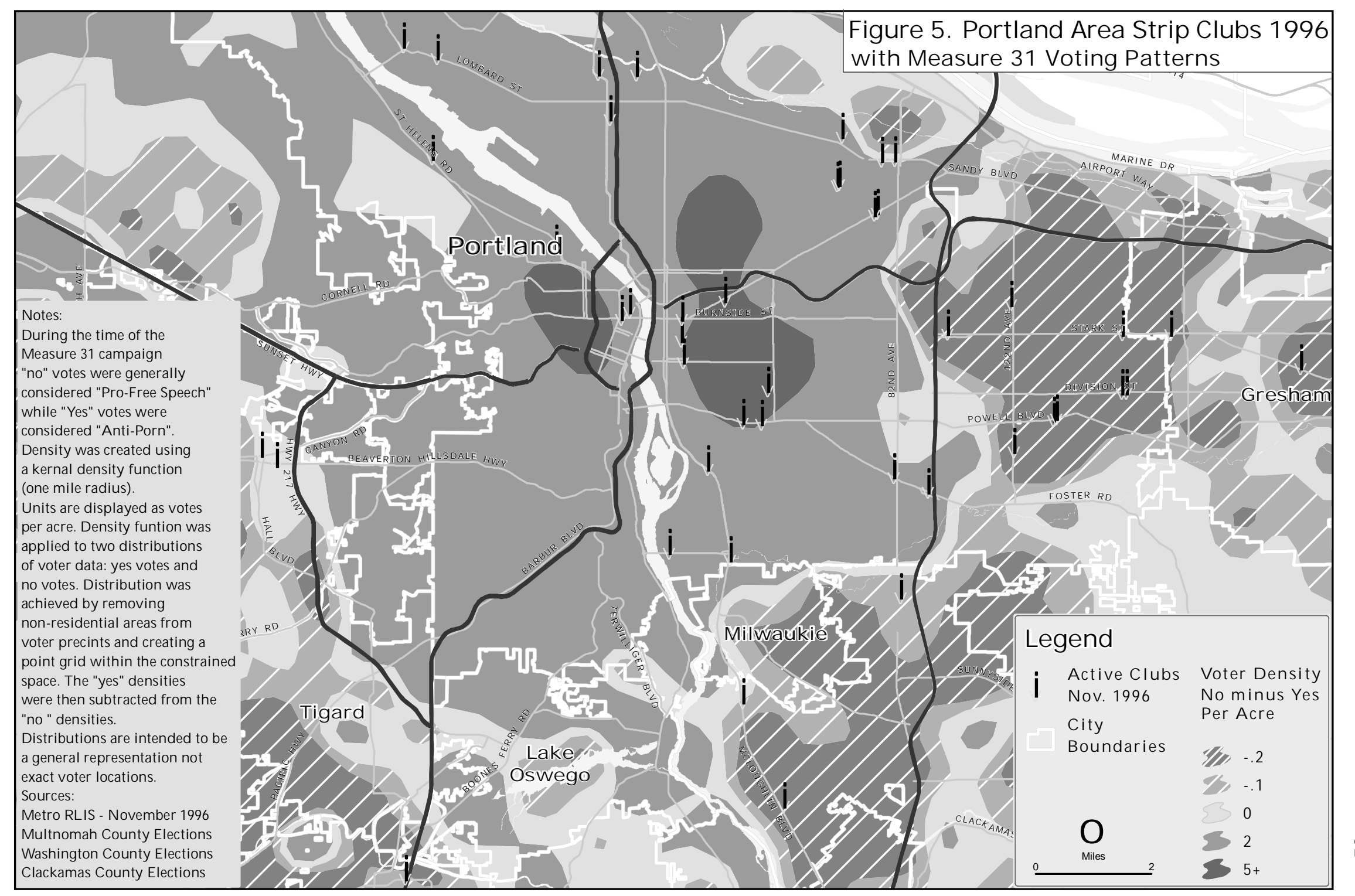

$\stackrel{\infty}{\sim}$ 


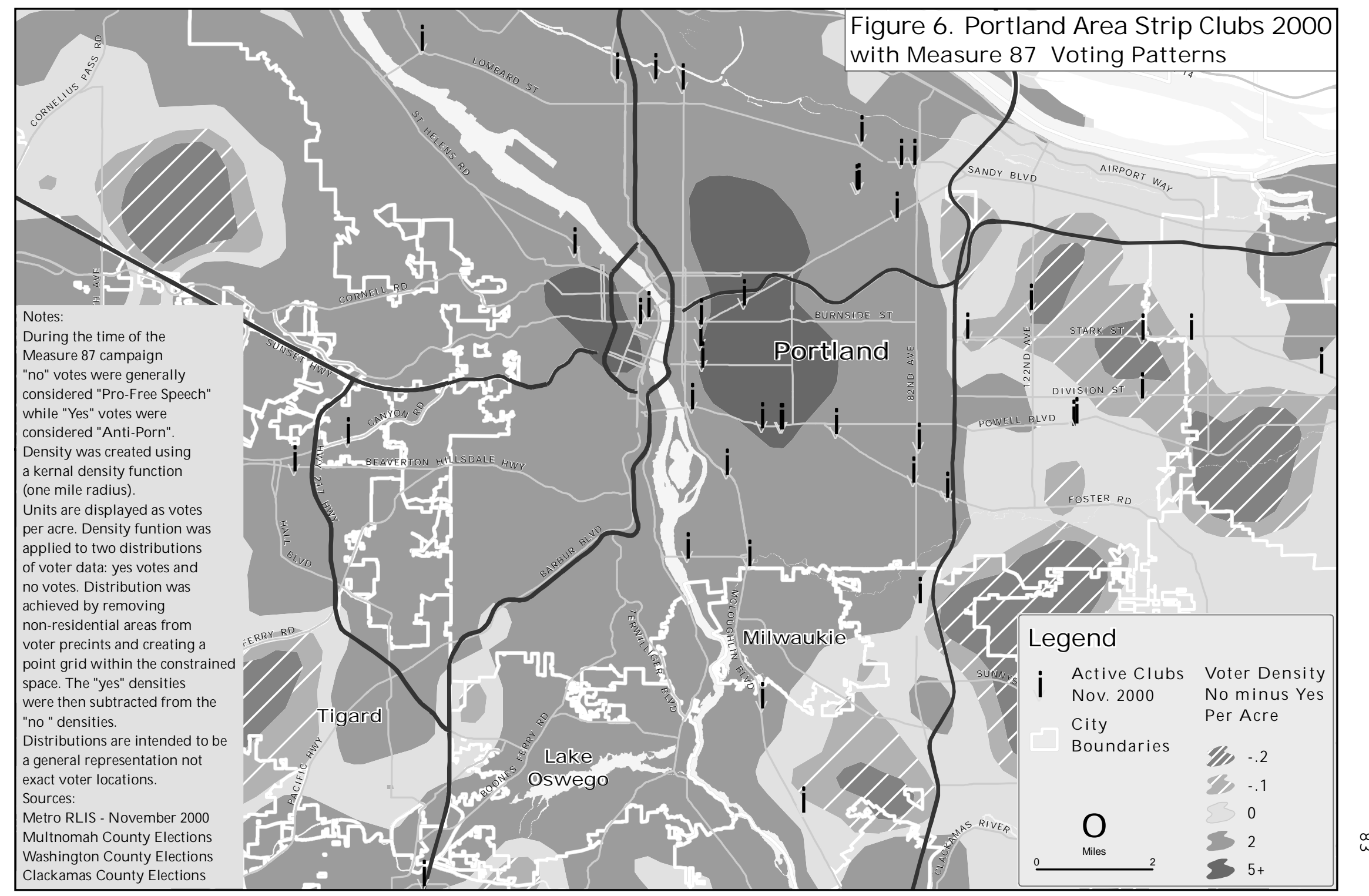


Appendix C

Methodology Statement 
Voter Distribution Analysis:

This analysis method was an experimental approach, which attempted to disaggregate voter data to better understand any possible relationships to the location of strip clubs in the Portland region. The data presented in Figures 1, 5, and 6 was created using voting results by precinct for the Oregon Counties of Clackamas, Multnomah, and Washington. Results were adjoined to spatial data files of precincts for the appropriate election years for use in geographic information system (GIS) analysis. Precincts were reshaped by removing non-residential areas determined from tax-parcel land-use codes. Voter results, both yes and no, were distributed randomly as points within the new, residentially constrained precinct shape.

Assumptions:

- Voters are evenly distributed with regard to residence type, no accounting for multi-unit versus single unit concentrations.

- Yes and no votes do not cluster. It is understood that these variable probably do cluster.

Random point distributions were created 10 times for both yes and no votes. For Figure 1 the distance from each club was determined using buffers. Each set of points were counted within the buffers and averaged. For Figures 5 and 6 a kernel density function was applied to each set of points and averaged using a raster calculation.

This methodology has not been subject to any statistical or geo-processing review. It is not intended to represent real voter locations or distributions and exists solely for the hypothetical analysis of strip club and resident relationships. 


\section{Appendix D}

\section{Ballot Measure Statements}


The Oregon Constitution; Article 1, Section 8:

"Freedom of speech and press. No law shall be passed restraining the free expression of opinion, or restricting the right to speak, write, or print freely on any subject whatever; but every person shall be responsible for the abuse of this right."

The following proposed amendments would appear as second paragraphs to Section 8.

1994, Measure 19:

"Article 1, Section 8 of this Constitution shall not be interpreted to prevent the people, the Legislative Assembly, or any City or County from enacting laws regulating or prohibiting obscenity, to the extent permitted by the United States Constitution. For purposes of this section, the term "obscenity" shall have the meaning given it by the United States Supreme Court, and in addition shall also include child pornography."

\section{6, Measure 31:}

"Obscenity, including child pornography, shall receive no greater protection under this Constitution than afforded by the Constitution of the United States."

The following proposed amendment would appear as a new section (42) in Article 1

2000, Measure 87:

"SECTION 42. (1) Notwithstanding section 8 of this Article, to the extent permitted by the United States Constitution, political subdivisions in this state may, through the use of zoning authority, regulate the location of sexually oriented businesses.

(2) As used in this section, "sexually oriented business" means a commercial establishment, the principal business of which is nude dancing, nude entertainment or the production, distribution or display of representations of sexual activity." 